\title{
Da polícia à política: explicando o perfil dos candidatos das forças repressivas de Estado à Câmara dos Deputados ${ }^{4}$
}

\author{
From Police to Politics: \\ analyzing the profile of candidates from the State's repressive Forces \\ to the Chamber of Deputies
}

\section{Introdução}

\section{O $9^{\circ}$ Anuário Brasileiro de Segurança Pública apontou que, em 2014, ao menos 58.497 pessoas foram mortas de maneira violenta}

1 É mestra e doutoranda em Sociologia pela Universidade Federal do Paraná (UFPR). Também é professora no curso de Especialização em Sociologia Política da mesma instituição, no módulo "Violência e Cidadania". É integrante do Centro de Estudos de Segurança Pública e Direitos Humanos (CESPDH) e do Observatório de Elites Políticas e Sociais do Brasil desta universidade. Realizou estágio sanduíche no Centre de Recherche Sociologique sur le Droit et les Institutions Pénales (Cesdip), vinculado ao Ministère de la Justice e à Université de Versailles Saint-Quentinen-Yvelines (França). E-mail: <fabiaberlatto@gmail.com>..

2 É doutor em Ciência Política pela Universidade Estadual de Campinas (Unicamp). Professor de Ciência Política na Universidade Federal do Paraná (UFPR), editor da Revista de Sociologia e Política (disponível em: <www.scielo.br/rsocp >) e um dos coordenadores do Núcleo de Pesquisa em Sociologia Política Brasileira da UFPR. Atua no Programa de Pós-Graduação em Ciência Política e no Programa de Pós-Graduação em Políticas Públicas na mesma instituição. Realizou estágio de pós-doutorado no Centre Européen de Sociologie et de Science Politique de la Sorbonne (Cessp-Paris). Coordena o Observatório de elites políticas e sociais do Brasil (disponível em: <http://observatory-elites.org/>). E-mail:<adriano@ufpr.br>.

3 É professor de Ciência Política na Universidade Federal do Paraná (UFPR). Possui doutorado em Ciência Política pela Universidade Federal de São Carlos (UFSCar) e mestrado em Sociologia pela UFPR. Realizou parte de seu doutoramento na University of Oxford no Latin American Centre. É pesquisador do Núcleo de Pesquisa em Sociologia Política Brasileira (Nusp) da UFPR, do Grupo de Investigações de Partidos e Sistemas Partidários da América Latina (Gipsal) da Asociación Latinoamericana de Ciencia Política (Alacip) e do Núcleo de Estudos dos Partidos Políticos Latino Americanos (Nepla) da UFSCar. Atua como editor-associado da Revista de Sociologia e Política (disponível em: <www.scielo.br/rsocp>). E-mail: <brunobolognesi@gmail.com>.

4 Este artigo resulta do estágio de doutorado de Fábia Berlatto no Centre de Recherches Sociologiques sur le Droit et les Institutions Penales no ano de 2015, financiado com uma bolsa da Coordenação de Aperfeiçoamento de Pessoal de Nível Superior (Capes) - Processo n 99999.008848/2014-09. Foi escrito em colaboração com Adriano Codato, que contou, para sua realização, com uma bolsa da Capes durante estágio de pós-doutorado no Departamento de Ciência Política da Universidade Paris 1 - Panthéon-Sorbonne, entre 2015 e 2016 - Processo no 99999.006157/2014-09. 
no país, vítimas de homicídio doloso, latrocínio, lesão corporal seguida de morte, vitimização policial e mortes decorrentes de intervenção policial. A taxa é de 28,8 mortes violentas para cada 100 mil habitantes (Lima e Bueno 2015, p. 6). Somados à representação midiática de eventos violentos, esses índices têm dado o tom do debate público sobre o tema e a consequente demanda por "mais segurança pública”, expressão que, na prática, têm significado mais repressão e uma repressão mais violenta, o que demonstra o aumento de $37 \%$ no número de mortes causadas pelas polícias brasileiras entre 2013 e 2014 (op. cit.). Pesquisa realizada pelo Instituto Brasileiro de Opinião Pública e Estatística (Ibope) em 2014 apontou uma adesão massiva (83\% dos respondentes) à redução da maioridade penal para os 16 anos de idade (Ibope, 2014). A Câmara dos Deputados engajou-se nessa proposta já no início da legislatura 2015-2019. A ideia avançou durante o ano de 2015.

Nesse contexto, o tema da "segurança pública" tornou-se muito produtivo para a agenda eleitoral. A experiência profissional dos agentes públicos incumbidos da segurança é um recurso social facilmente instrumentalizável durante as campanhas, uma vez que demandas nesse campo tendem, em geral, para o reforço e/ou a ampliação das formas mais repressivas de controle social. Durante sua expedição para deputado federal em 2014, Cabo Sabino (PR/ $\mathrm{CE}$ ), eleito, deu uma declaração exemplar: "somos candidatos para melhorar a segurança pública. Temos a experiência e a vivência de policial militar, conhecendo de perto as deficiências, as necessidades das comunidades. Nessa área de segurança, ninguém pode contribuir mais [do] que os policiais" (Madeiro, 2014).

No entanto, os interesses e os propósitos implicados no engajamento político das categorias sociais de Estado envolvidas diretamente com segurança e repressão são mais diversos. Há a necessidade de debater com a sociedade os problemas da segurança pública e suas instituições, incluindo as implicações na qualidade de vida e de trabalho dos policiais, de se discutir a atual estrutura 
organizacional das corporações, ${ }^{5}$ suas diferenças salariais internas e as dificuldades de ascensão na carreira. Há os conflitos nas relações cotidianas de trabalho dos diferentes níveis hierárquicos entre agentes e delegados nas Polícias Civis e entre praças e oficiais nas corporações militares estaduais etc. Esses fatores estimulam não só o envolvimento com a política partidária, mas também a construção de associações de classe, a organização de paralizações, a abertura de novos canais de expressão e de relação intra e extracorporação como sites, blogs e contas no Twitter. Ramos e Paiva (2009), em pesquisa sobre a blogosfera policial, contaram aproximadamente 70 blogs em 2009, dos quais $82 \%$ foram criados entre 2007 e 2009 . Suas entrevistas mostraram que $40 \%$ deles acreditam que ser blogueiro "é um meio de expressão política", 31,4\% disseram que é "parte do trabalho" e 17\% um "serviço público" (Ramos e Paiva, 2009). ${ }^{6}$

Entre 1998 e 2014, 23.219 indivíduos concorreram à posição de deputado federal no Brasil. Desse total, 972 integrantes das Forças Repressivas Civis e Militares candidataram-se a essa posição política, ou seja, 4,2\%. Este artigo faz uma radiografia social e política desse grupo de candidatos, apontando suas transformações ao longo do tempo e indagando sobre suas possíveis causas.

Estudos sobre candidatos e eleitos têm avançado significativamente nos últimos anos. Disputas têm sido analisadas por cientistas políticos preocupados em determinar o perfil de carreira,

5 A atual estrutura policial brasileira é assim organizada: Polícia Federal, Polícia Rodoviária Federal, Polícia Ferroviária Nacional e Guarda Nacional, pertencentes à União; Polícia Civil, Polícia Militar e Bombeiros Militares pertencem ao nível estadual da administração (as duas últimas são reservas e forças auxiliares do Exército e, portanto, são Forças Militarizadas). Há também a Guarda Municipal, que pouco a pouco vem recebendo status de polícia no Brasil e cuja composição é facultativa e de responsabilidade dos municípios.

6 Segundo as autoras, o Sudeste é a região dominante, com o Rio de Janeiro em primeiro lugar, seguido de São Paulo e Minas Gerais no número de blogs. Elas apontam, ainda, que a blogosfera policial é composta majoritariamente por policiais militares homens, em sua maior parte pertencentes aos estratos mais baixos das instituições policiais, com alta escolarização e mais de 30 anos. 
os atributos sociais, o potencial econômico e suas redes de relações. ${ }^{7}$ Ao mesmo tempo, subgrupos de candidatos selecionados conforme o sexo, a cor, a idade, o capital escolar, as capacidades de levantar financiamentos para campanhas, o ofício e as redes associativas que mobilizam, são esquadrinhados. ${ }^{8}$ Todavia, a atenção crescente que a questão da segurança pública tem recebido no Brasil nas últimas três décadas pelo menos (Vasconcelos, 2014) não foi acompanhada por pesquisas que investigassem quem são os agentes das polícias e os integrantes das Forças Armadas que se lançam na política institucional. Uma exceção é a análise de Baird e Pollachi (2014), concentrada na composição e na atuação da Comissão de Segurança Pública da Câmara dos Deputados. Tradicionalmente, trabalhos que focalizam ocupações de origem dos parlamentares classificam todos os agentes das Forças de Segurança e Repressão do Estado como "funcionários públicos", na mesma categoria em que podem entrar professores do Ensino Superior público, baixo e médio funcionalismo, diretores de bancos estatais, burocratas com posições nas cúpulas do Estado (Codato, Ferreira e Costa, 2015; Rodrigues, 2002b).

Neste trabalho, analisamos os candidatos a deputado federal no Brasil nas últimas cinco eleições (1998, 2002, 2006, 2010 e 2014), cuja origem profissional declarada nos registros de candidatura do Tribunal Superior Eleitoral (TSE) foi policial civil, policial militar, bombeiro militar e membro das Forças Armadas (da ativa ou reformado). A percepção convencional sobre esse grupo é que seus integrantes são exclusivamente de direita, reúnem-se sob as siglas dos grandes partidos conservadores e representam correntes autoritárias de opinião da sociedade, que suas campanhas mobilizam temas como redução da maioridade penal, aumento dos

$7 \quad$ A literatura aqui é expressiva, em especial depois dos estudos pioneiros de Marenco dos Santos (1997; 2001) e de Rodrigues (2002a; 2006). A título de exemplo, ver Araújo (2011), Bolognesi, Perissinotto e Codato (2016), Cervi et al. (2015), Codato, Cervi e Perissinotto (2013), Miguel, Marques e Machado (2015), Pereira e Rennó (2013), Perissinotto e Bolognesi (2010), Perissinotto e Veiga (2014) e Power e Mochel (2009).

8 Ver, entre outros, Araújo e Borges (2013), Meneguello et al. (2012), Campos e Machado (2015), Llanos e Sánchez (2006), Almeida, Lüchmann e Ribeiro (2012), Speck e Mancuso (2014) e Campos (2015). 
efetivos policiais, aprofundamento da repressão violenta ao crime e liberação do porte de armas, além de uma agenda conservadora em questões comportamentais. De fato, um exame dos dados agregados mostra que $70 \%$ destes candidatos lançaram-se por partidos de direita, embora estivessem presentes em todos os partidos do espectro ideológico. Propomos aqui uma análise contextual do perfil desse grupo de 972 candidatos, analisando suas opções político-partidárias e as mudanças ao longo do intervalo 1998-2014. Nosso interesse primordial é compreender e explicar quem são eles e por qual tipo de partidos eles se lançam.

$\mathrm{Na}$ sequência, apresentamos os dados com os quais trabalhamos, as agregações que fizemos e algumas dificuldades que o banco de candidatos e eleitos do TSE do Brasil oferece para análises mais detalhadas. A segunda seção contextualiza o objeto - os "candidatos-policiais" - e discute as condições de sua afinidade ou não com o mundo da política profissional. A terceira seção explica o enquadramento legal das candidaturas de militares e policiais no Brasil comparativamente a países da América Latina e da Europa. Na quarta seção expõe-se, a partir de estatística descritiva, os dados básicos sobre esse universo de candidatos a deputado. Na última seção, separamos as candidaturas por blocos ideológicos e partidários, a fim de destacar o papel dos pequenos partidos de direita e a ascensão dos partidos fisiológicos no recrutamento e na mobilização destes candidatos entre 1998 e 2014 . A partir do perfil destes partidos, tentamos uma explicação acerca do potencial de atração dessas legendas como recurso eleitoral para os candidatos-policiais.

\section{Materiais e métodos}

Os dados foram coletados e sistematizados a partir do registro das candidaturas no TSE. Compilamos um banco com 23.219 indivíduos, sendo 972 membros das Forças de Segurança e Repressão do Estado brasileiro. Consideramos aqui apenas a ocupação autodeclarada pelos candidatos. Isso impediu que fossem recuperados por completo todos os indivíduos pertencentes às Forças 
Repressivas do Estado que se alistaram, como os integrantes da Polícia Federal, por exemplo. Os candidatos vindos das Polícias Federais ficaram de fora porque eles invariavelmente alistam-se para concorrer como "funcionário público federal". Além disso, uma vez eleitos, é comum que os candidatos à reeleição passem a se assumir ou a declarar como profissão, na disputa seguinte, o cargo que ocupam no momento do cadastro eleitoral (deputado, vereador, prefeito etc.). Não há, enfim, um padrão nos registros sobre profissão pelo TSE e os policiais civis ou militares podem apresentar-se de diferentes maneiras. Podem, inclusive, mudar sua ocupação toda vez que concorrem em determinada eleição. Jair Bolsonaro é um caso típico. Em 1998 concorreu a deputado federal pelo PPB-RJ e se alistou como "membro das Forças Armadas". Já em 2002 declarou-se pertencente ao grupo de políticos profissionais (“senador, deputado e vereador"). Em 2006, optou por apresentar-se pelo PP-RJ como "militar reformado". Em 2010 e em 2014, preencheu novamente o registro de candidato do TSE como "político". Em função dessas oscilações, os candidatos somente entraram na base de dados e integraram o universo de 972 policiais civis/militares se e quando se registraram espontaneamente ou como policial ou como militar. O tempo necessário para conferir uma a uma as ocupações declaradas dos mais de 23 mil candidatos no intervalo aqui observado, a fim de verificar se a autoatribuição não mascarava a ocupação efetiva, forçou-nos a manter a autodeclaração. Isso, sem dúvida, cria dificuldades para se contar o número de eleitos, o que nos impediu de incluí-los neste artigo. ${ }^{9}$ Essa falta subestima o papel deste grupo na

9 Conforme análise do perfil dos eleitos pelo Departamento Intersindical de Assessoria Parlamentar (Diap), em 2014, 22 deputados federais cuja origem são as Forças de Segurança foram eleitos para a Câmara dos Deputados (Diap, 2014, p. 94) e cinco deles estavam na lista dos mais votados. Fraga (Democratas do Distrito Federal - DEM-DF), coronel da reserva da Polícia Militar do Distrito Federal, recebeu 10,66\% dos votos válidos (alcançou 155.056 votos). O capitão do Exército Jair Bolsonaro (PP-RJ) teve 6,1\% dos votos válidos (464.572). O candidato Delegado Waldir (PSDB-GO) ficou com 9,6\% dos votos válidos (274.675). Moroni (DEM-CE), com 6,36\% dos votos válidos (277.774), e Delegado Eder Mauro (PSD-PA), com 7,8\% (265.983). Pelo critério de autodeclaração, seriam apenas seis os eleitos (Cabo Daciolo, Capitão Fabio Abreu, Fraga, Capitão Augusto, Delegado Laerte Bessa e Delegado Waldir). 
política nacional e sua grande visibilidade eleitoral, mas, por outro lado, garante um tratamento uniforme para o universo de candidatos. Nesse sentido, a base de dados apresenta, como de hábito, problemas de confiabilidade. Porém, com esse recorte temporal amplo e com essa quantidade de indivíduos, o ruído é normalmente distribuído.

Além disso, há uma segunda dificuldade nos assentamentos oficiais. Conforme o próprio registro dos candidatos, o TSE dividiu em 1998 os agentes de segurança do Estado em três grupos: policial civil, membro das Forças Armadas da ativa (não indicando quantos pertenciam ao quadro das polícias estaduais) e militar reformado. A partir de 2002, as ocupações que nos interessam aqui foram ordenadas de maneira mais detalhada em cinco classes diferentes: bombeiro militar, membro das Forças Armadas, militar reformado, policial civil e policial militar. A fim de padronizar as informações para as cinco eleições e, ao mesmo tempo, manter alguma singularidade no interior desse universo complexo e com grandes diferenças internas entre os subgrupos (formas de investidura, ethos, salários, regimes funcionais etc.), recodificamos as cinco ocupações originais em apenas duas grandes classes. Unificamos militares aposentados ("reformados"), militares do serviço ativo das três Forças, bombeiros militares e policiais militares em uma única categoria: "militar". Mantivemos os policiais civis em uma segunda categoria separada: "civis".

Trabalhar com as patentes dos candidatos militares ou com as especialidades profissionais dos policiais civis também se revelou inviável. No caso dos civis, não há qualquer informação se investigador, delegado, agente penitenciário etc. Para ser preciso, apenas oito em 108 candidatos apresentaram-se como "delegado fulano de tal" (menos do que os 13 que incluíram "Dr." antes dos nomes de urna). No caso dos militares, as patentes, seja das Polícias Militares, seja das Forças Armadas, seriam uma informação estratégica para hierarquizar o subgrupo. Essa informação poderia ser extraída dos nomes de urna dos candidatos (nomes políticos que são usados nas campanhas e aparecem na máquina de votação). 
Alguns fizeram questão de se identificar como cabo, capitão, coronel etc., mas esses são em torno de 30\% do grupo, apenas.

A tabela 1 sumariza o total de candidatos-policiais e não policiais por disputa a cada ano do intervalo considerado. A fim de unificar a linguagem, englobamos todos esses indivíduos na categoria de "membros das Forças Repressivas do Estado", integrantes das "polícias" ou "policiais". Esses apelativos são, antes de tudo, uma anotação taquigráfica para um grupo que, como pretendemos mostrar, é bem mais complexo politicamente.

Tabela 1 - Candidatos a deputado federal no Brasil entre 1998 e 2014 oriundos das polícias e não (em números absolutos e percentuais)

\begin{tabular}{|c|c|c|c|c|c|c|c|c|}
\hline & & & \multicolumn{5}{|c|}{ Ano de eleição } & \multirow{2}{*}{ Total } \\
\hline & & & 1998 & 2002 & 2006 & 2010 & 2014 & \\
\hline \multirow{4}{*}{ Policial } & \multirow{2}{*}{ Não } & $\mathrm{N}$ & 3.258 & 4.011 & 4.689 & 4.666 & 5.623 & 22.247 \\
\hline & & $\%$ & $96,4 \%$ & $96,0 \%$ & $94,9 \%$ & $95,5 \%$ & $96,4 \%$ & $95,8 \%$ \\
\hline & \multirow{2}{*}{ Sim } & $\mathrm{N}$ & 120 & 168 & 254 & 221 & 209 & 972 \\
\hline & & $\%$ & $3,6 \%$ & $4,0 \%$ & $5,1 \%$ & $4,5 \%$ & $3,6 \%$ & $4,2 \%$ \\
\hline \multirow{2}{*}{\multicolumn{2}{|c|}{ Total }} & $\mathrm{N}$ & 3.378 & 4.179 & 4.943 & 4.887 & 5.832 & 23.219 \\
\hline & & $\%$ & $100,0 \%$ & $100,0 \%$ & $100,0 \%$ & $100,0 \%$ & $100,0 \%$ & $100,0 \%$ \\
\hline
\end{tabular}

Fonte: Observatory of Social and Political Elites of Brazil (disponível em: <http://observatory-elites.org/>), e Nusp/UFPR.

Utilizamos dois critérios para a classificação dos partidos políticos brasileiros: tamanho e ideologia.

Para tamanho, adotou-se a seguinte medida: fizemos uma média do número de cadeiras conquistadas por partido nas cinco eleições consideradas no estudo e dividimos os partidos em dois grupos: grandes e pequenos. Todavia, há uma variação muito grande entre as siglas. O DEM/PFL teve, em média, 63,8 cadeiras; o PDT 23,2; o PROS 11; o PV 8; e o PRN/PTC 1,2, por exemplo. Utilizamos $z$-escore a fim de estandardizar os valores e permitir comparar as médias desse conjunto de dados. O z-escore é uma 
forma de expressar, de modo padronizado, a posição relativa de uma observação no interior de uma distribuição. Ele indica quantos desvios padrão uma observação está acima ou abaixo da média. Para os valores positivos, assumimos que eram partidos grandes; para os valores negativos, pequenos (ver os cálculos no Apêndice A, tabela A1). Grosso modo, siglas que controlaram mais de 3\% das cadeiras na Câmara dos Deputados, em média, são grandes. Menos do que isso, pequenas.

Há diferentes formas de mensurar a dimensão de um partido político. Dantas e Praça (2010) e Rodrigues (1995) classificam os partidos a partir do desempenho eleitoral para a Câmara dos Deputados. Ev e Melo (2014) classificam os partidos com base na distribuição do voto no território e número de prefeituras e cadeiras de deputados federais conquistadas. Guarnieri (2011) não realiza uma análise sobre o tamanho dos partidos, mas fornece pistas para estabelecer critérios sobre a robustez partidária a partir da infraestrutura organizacional. $\mathrm{O}$ autor classifica como partidos "fracos" aqueles que possuem estrutura fluída e provisória, o que ocorre com a maior parte dos partidos aqui classificados como pequenos. Ele tenta relativizar o uso de cortes absolutos e uma metodologia que classifique os partidos de forma relacional, realizando um cluster que leve em conta o peso relativo de cada agremiação em relação à outra. Nascimento et al. (2016) tentam estabelecer o que seria um partido pequeno (ou médio ou grande) com base na votação nominal nas eleições de 1998 a 2014. Ainda, o fazem tendo em vista a relação entre os partidos em cada estado.

Contudo, as análises que dependem das variações regionais e/ou de outputs estatísticos são pouco úteis para comparações longitudinais, já que não conseguem estabelecer um corte comum ao mesmo partido ao longo do tempo. Por essa razão, nossa classificação tenta criar um intervalo comparável em que possamos alocar o mesmo partido ao longo do tempo, assemelhando-nos aos critérios mobilizados por Dantas e Praça (2010).

Para ideologia, analisamos um conjunto de informações programáticas e eleitorais dos partidos políticos e distribuímos 
as agremiações em três classes: direita, centro e esquerda. $\mathrm{O}$ critério para o estabelecimento dessas posições baseou-se no cânone da divisão entre esquerda e direita partidária (Coppedge, 1998; Madeira e Tarouco, 2011; Tarouco e Madeira, 2013a; Zucco Jr., 2011). Partidos que manifestaram em seus programas eleitorais posições a favor da intervenção do Estado na economia e sentenças em defesa da igualdade e do liberalismo comportamental, foram classificados como "esquerda". Por outro lado, partidos que defendem a plataforma do Estado mínimo e posições conservadoras no campo comportamental, foram rotulados como "direita”. Aqueles partidos que manifestaram posições mistas ou conflitantes em relação a esses temas, foram classificados como "centro". No universo de partidos presentes há desde partidos de fácil verificação sobre sua posição ideológica até outros que não dão mais do que uma ou duas pistas de sua carta de intenções. Dizer que o PT é um partido de esquerda ou que o PFL/ DEM está na direita parece bastante óbvio e consistente. Ambos contam com largo material para observação eleitoral: alianças, propaganda, discursos; bancada legislativa e posições executivas que nos relevam as políticas públicas perseguidas pelos partidos; longa existência que permite analisar os programas de partido; programas de governo etc. Porém, como fazer com partidos em que essas fontes de observação são escassas ou não existem? A solução por nós adotada foi combinar dois critérios: $i$ ) as informações presentes no programa do partido, na sua carta de intenções ou no seu manifesto; e ii) o comportamento eleitoral da legenda na última ou nas últimas eleições. Partidos novos, nanicos ou inexpressivos (como PROS, PHS, PT do B, PAN e SD) possuem pouco material para consulta, de modo que não há outra alternativa que não seja olhar para esses materiais. ${ }^{10}$

10 Basta dizer que mesmo os trabalhos que tentaram uma classificação de todos os partidos políticos brasileiros falharam também na hora de analisar os nanicos e a solução dada pela literatura foi deixá-los de fora dos estudos. Ver, por exemplo, Coppedge (1997), Power e Zucco Jr. (2009) e Tarouco e Madeira (2013b). 
Além disso, criamos a classe "pequenos partidos fisiológicos". Partidos "fisiológicos" são partidos sem ideologia política definida, nem expressão representativa clara, ou seja, não sustentam nenhum grupo de interesse específico (como partidos "verdes" ou os "trabalhistas" o fazem, por exemplo). São pragmáticos, na falta de um termo mais preciso e que não carregue juízo de valor. Dada a abertura do sistema eleitoral brasileiro, em que a inexistência de lista fechada e as altas magnitudes tendem a asseverar o personalismo, o terreno é fértil para surgimento de partidos que sirvam aos interesses de uma família, de um líder, existam apenas para captar recursos do Estado ou servir como legenda de aluguel e moeda de troca na distribuição do horário eleitoral gratuito nas eleições majoritárias. São partidos que desfrutam de um poderoso incentivo dado pelo Estado (como a facilidade de acesso aos recursos do fundo partidário (Bolognesi, 2016) e tornam-se um emaranhado de letras sem nenhuma expressão social ou política que não dependa das relações clientelísticas promovidas pelas elites das legendas.

Assim, conforme nossa classificação, temos: grandes de centro: PMDB, PSDB; grandes de direita: DEM/PFL, PL, PP/PPB, PR, PSD (K), ${ }^{11} \mathrm{PTB}$; grandes de esquerda: PDT, PSB, PT; pequenos de direita: PEN, PRB, PRN, PRONA, PRP, PRTB, PSC, PSD*, PSDC, PSL, PSN, PST, PTC, SD; pequenos de centro: PV, PPS; pequenos de esquerda: PC do B, PCB, PCO, PPL, PSOL, PSTU; pequenos fisiológicos: PAN, PGT, PHS, PT do B, PTN, PMN, PROS.

11 No universo analisado, constam partidos que não existem mais, como o antigo PSD. Estão aqui presentes por terem disputado ao menos uma eleição no período 1998-2014. Para realçar agremiações diferentes, mas com mesma sigla, adotamos a seguinte notação: PSD (K) para o Partido Social Democrático criado em 2011 por Gilberto Kassab; para o Partido Social Democrático que, em 1989, concorreu à Presidência da República com Ronaldo Caiado, e depois passou a ser dirigido por Nabi Abi Chedid e foi incorporado ao PTB em 2003, adotamos a notação PSD*. O atual DEM é o antigo PFL e o atual PP o antigo PPB, que apenas mudaram de nome; o atual PR é o antigo PL e o PTC é o extinto PRN. Nesses quatro casos, consideramos seus candidatos e eleitos como continuações. Para o significado das siglas dos partidos políticos brasileiros citados, veja o Apêndice B. 


\section{As polícias e as vocações políticas}

Indivíduos são socializados em suas respectivas profissões e adquirem habilidades que podem ser reconvertidas para uso e exibição no universo político. Os casos clássicos de uso eficiente dos atributos são jornalistas e advogados (Weber, 1994). A intimidade dessas talking professions (Norris e Lovenduski, 1995) com as mesmas qualidades exigidas na política - a oratória desinibida, a disposição para defender causas, o conhecimento das leis - dão a esses profissionais uma vantagem considerável para mover-se em um universo social restrito e muito competitivo. De acordo com essa perspectiva, ocupação de origem seria um fator relevante para o sucesso político nas democracias competitivas.

Contudo, o que policiais e militares podem ter a ver com a política institucional? A Polícia Civil possui várias carreiras (agente policial, escrivão de polícia, agente penitenciário, investigador, médico legista, perito criminal), mas, mesmo que existam diferenças nos diversos estados, somente se exige curso superior em Direito dos delegados. Porém, a atividade desses bacharéis não se concentra em defender causas, nem exige dons de oratória ou capacidade de negociação como a dos políticos de ofício. No caso dos policiais militares e dos agentes das Forças Armadas, há impedimento legal de filiar-se a partidos políticos. Em função da vida militar - que significa rotinas estritas, valores específicos, forte espírito de corpo -, candidatos desse tipo têm menor sociabilidade no mundo "paisano" (civil). Isso afeta suas capacidades de estabelecer redes mais amplas de contato e de conseguir votos que extrapolem o entorno da caserna. A dificuldade, portanto, está em como converter um "capital de função" (Bourdieu, 1981, p. 19) em "capital eleitoral”. Ainda assim, e apesar dessa afinidade disposicional negativa com a política institucional, os números relativos dessas candidaturas não são desprezíveis (rever a tabela 1).

Por outro lado, há também vantagens consideráveis para as ocupações policiais engajarem-se em disputas eleitorais no Brasil. Caso os candidatos-policiais consigam manter suas vinculações 
com suas instituições de origem, eles têm garantido seus ordenados pagos pelo Estado. É essa renda regular o que avaliza que eles sejam "economicamente independentes" (Weber, 1994) das rendas que a política possa lhes proporcionar e possam lançar-se na disputa com a certeza de que seu sustento não dependerá da vitória na eleição (ao contrário dos trabalhadores manuais, por exemplo). E é essa renda que permite que estejam, uma vez asseguradas as suas condições de existência, "economicamente disponíveis" (op. cit.), isto é, tenham tempo livre para fazer política, um recurso fundamental.

Além disso, como em qualquer outra profissão, corporações policiais desenvolvem interesses próprios. Nelas podem surgir, como de fato surgem, notoriedades pessoais: comandantes carismáticos, ativistas de diferentes causas, principalmente trabalhistas, líderes de greves, agenciadores de questões com grande apelo social (a luta contra "a violência", "a criminalidade", "a corrupção", "a impunidade" etc.) e, naturalmente, os paladinos de causas ultraconservadoras. Há todo incentivo institucional para que candidaturas personalistas assim prosperem mesmo com pouca identificação partidária, já que, como se verá na seção seguinte, militares não podem militar em partidos políticos. Depois, o sistema eleitoral brasileiro e as próprias agremiações incentivam disputas em que as campanhas tendem a ser centradas no candidato (Samuels, 1997; 1999). Os campeões de voto das polícias são, assim, o efeito do individualismo ou do personalismo que tende a animar todo esse sistema. Este personalismo, que produz a figura do "xerife" da segurança pública, aquele indivíduo que se incumbe ou que é incumbido de resolver autoritariamente a insegurança pública, casa-se com a predisposição dos eleitores em identificar as causas da criminalidade ora 
na maldade das pessoas, ora no pouco policiamento das cidades (Editores de Opinião Pública, 2014). ${ }^{12}$

O número de candidatos cuja origem profissional são as Forças de Segurança explica-se também pelo fato de essas categorias sociais de Estado considerarem-se pouco ou nada assistidas politicamente, desvalorizadas socialmente e, no caso específico dos policiais e bombeiros militares, não partilharem dos direitos civis garantidos constitucionalmente ao restante dos brasileiros. A manutenção da estrutura militarizada desses órgãos não facilitou em nada a sua adequação institucional ao contexto democrático, permanecendo as dificuldades em se abrir ao diálogo e ao controle externo (Cano, 2006; Lima e Costa, 2014; Soares, 2005). Apesar disso, há setores dessas categorias atentos aos debates sobre os direitos sociais pós-Constituição de 1988 e com atuação cada vez mais reivindicatória. A percepção, entre bombeiros e policiais militares, da não observação de suas demandas trabalhistas pelos governos, do contraste existente entre o regime democrático, muito mais propício para a expressão de suas plataformas, e o seu cotidiano profissional baseado em preceitos muito rígidos de hierarquia e disciplina, fez crescer nos últimos anos seu protagonismo político de diferentes maneiras. ${ }^{13}$

\section{O quadro legal das candidaturas dos militares e dos policiais civis}

A legislação brasileira que trata dos direitos políticos dos militares (votar, ser votado e participar de partido político) comporta

12 Em 2008, 36,1\% dos brasileiros achavam que a principal causa da criminalidade era o pouco policiamento, seguida da pobreza (27,6\%) e do uso de drogas (19,5\%) (Pesquisa CNI/lbope/Brasil 08.nov.-03192. Respostas estimuladas). Em 2012, quando confrontados com duas alternativas sobre a maior causa da criminalidade, a falta de oportunidades iguais a todos ou a maldade das pessoas, 59,8\% escolheram a segunda (Pesquisa Datafolha/Brasil 12.dez.-03372, citado a partir de Editores de Opinião Pública, 2014).

13 Além da já citada e marcável atuação da blogosfera policial, esse protagonismo político e suas reivindicações dão-se, também, por meio do fortalecimento do associativismo entre essas categorias profissionais. Tal fortalecimento é notado, por exemplo, na aprovação, pela Comissão de Trabalho da Câmara, em 2012, do Projeto de Lei (PL) n 364/2011, que dispensa policiais e bombeiros militares de suas funções quando eleitos para confederações, federações ou associações representativas e permite descontos das contribuições em folha de pagamento. Mais informações disponíveis em: <http://goo.gl/SUxK2F>. 
uma peculiaridade. Diferentemente dos seus vizinhos sul-americanos, militares brasileiros da ativa (policiais militares, bombeiros militares e membros do serviço ativo das Forças Armadas) podem concorrer a cargos eletivos e, se possuírem mais de dez anos de serviço nas suas respectivas corporações, podem retornar para os seus quadros de origem depois de terminado o mandato político. A exceção são os conscritos, isto é, aqueles que estão prestando serviço militar obrigatório. Estes são inalistáveis (e, portanto, inelegíveis). ${ }^{14}$ Aqueles que estão nas carreiras militares há menos de dez anos devem, por outro lado, caso sejam oficiais, afastarem-se definitivamente (se forem praças, devem apenas solicitar uma licença). ${ }^{15}$ Militares brasileiros, quando eleitos para alguma posição política, passam à reserva remunerada das Forças Armadas.

Militares da reserva são alistáveis e elegíveis, além de poderem se filiar a agremiações partidárias. Já a militância partidária é proibida a todos os militares da ativa. ${ }^{16}$ Essa contradição - a condição de elegibilidade no Brasil depende explicitamente de uma filiação partidária (Constituição de 1988, art. 14, \$3º - é solucionada exigindo-se que os militares da ativa vinculem-se formalmente aos partidos políticos apenas quando forem apontados oficialmente como candidatos pela convenção da legenda, o que faz com que, na prática, concorram a um lugar na lista do partido sem serem membros dele. Na Colômbia, os militares não

14 Constituição da República Federativa do Brasil de 1988, art. 14, § 2º disponível em: <http:// www.planalto.gov.br/ccivil_03/constituicao/constituicaocompilado.htm>. Uma hipótese para a origem dessa disposição é "evitar que os comandantes de grandes efetivos militares se elegessem com os votos de seus conscritos (que representam a maioria esmagadora das tropas, principalmente após a [...] instituição do Serviço Militar Obrigatório no Brasil, em 1908)" (Pires e Amorim, 2006, p. 5).

15 Recurso Especial Eleitoral n 20.318/2002.“OTSE, na Consulta n 571 (Resolução n 20.598/2000), respondeu à indagação sobre o significado da expressão afastar-se da atividade nos seguintes termos: 'o afastamento do militar de sua atividade, previsto no art. 14, § 8०, I, da Constituição, deverá se processar mediante demissão ou licenciamento ex officio, na forma da legislação que trata do serviço militar e dos regulamentos específicos de cada Força Armada"' (Pires e Amorim, 2006).

16 Constituição de 1988, art. 142, §30, inciso V (Pires e Amorim, 2006). No Brasil, magistrados, membros do Ministério Público e dos Tribunais de Contas também não podem se inscrever em partidos políticos. 
podem sequer votar e, no Equador, eles adquiriram esse direito apenas em 1998. Peru, Bolívia, Uruguai e Argentina proíbem seus quadros militares de desempenhar função pública eletiva e de participar de partido político, mas permitem que votem (Salgado, 2013). Por sua vez, policiais civis não possuem qualquer barreira legal para participar da política institucional. Daí que fosse esperável um contingente muito maior de policiais civis entre os candidatos, por exemplo. Mas não é o que ocorre. Embora a diferença venha caindo, há aproximadamente uma relação de 90\% de militares contra 10\% de civis (ver gráfico 2, mais adiante).

Em relação à Europa, um levantamento das legislações eleitorais de Portugal, da Espanha, da França, da Itália e da Alemanha mostrou que militares inativos não possuem restrição à participação política em nenhum dos casos. Militares da ativa, no entanto, não são elegíveis, à exceção de dois países: a Itália permite que seus militares de baixo escalão candidatem-se (mantendo a inelegibilidade de generais, almirantes e oficiais superiores), e a Alemanha, que não impõe restrições. Aliás, a Alemanha não restringe os direitos políticos de seus militares que podem, inclusive, filiar-se a partidos políticos. Uma exceção em relação a todos os países observados.

O quadro 1 resume as disposições de cinco países selecionados da Europa e do Brasil. 
Quadro 1 - Direito de participação dos militares e policiais na política: países selecionados

\begin{tabular}{|c|c|c|c|c|c|c|c|}
\hline & & Brasil & Portugal* & Espanha** & França $a^{* * *}$ & Itália ${ }^{* * * *}$ & Alemanha ${ }^{* * * * *}$ \\
\hline \multicolumn{2}{|c|}{ Alistamento } & Sim & Sim & Sim & Sim & Sim & Sim \\
\hline \multirow[b]{2}{*}{ Elegibilidade } & Inativos & Sim & Sim & Sim & Sim & Sim & Sim \\
\hline & Ativos & Não & Não & Não & Não & $\begin{array}{c}\text { Inelegibilidade } \\
\text { de generais, } \\
\text { almirantes } \\
\text { e oficiais } \\
\text { superiores } \\
\text { das Forças } \\
\text { Armadas }\end{array}$ & Sim \\
\hline
\end{tabular}

\begin{tabular}{|c|c|c|c|c|c|}
\hline Filiação partidária & $\begin{array}{c}\text { Não } \\
\text { (militares); sim } \\
\text { (policiais civis) }\end{array}$ & $\begin{array}{l}\text { Não (militares ou } \\
\text { agentes militarizados } \\
\text { dos quadros } \\
\text { permanentes em } \\
\text { serviço efetivo; } \\
\text { agentes dos serviços } \\
\text { ou das Forças de } \\
\text { Segurança em } \\
\text { serviço efetivo) }\end{array}$ & Não & Não & Não \\
\hline
\end{tabular}

Fonte: Observatory of Social and Political Elites of Brazil (disponível em: <http://observatory-elites.org/>), e Nusp/UFPR.

Notas: * Lei Eleitoral da Assembleia da República (Lei n 14, de 16 de maio de 1979) e Lei dos Partidos Políticos (Lei Orgânica nº 2, de 22 de agosto de 2003, com as alterações introduzidas pela Lei Orgânica n 2, de 14 de maio de 2008).

** Ley Orgánica nº 5, de 19 de junio de 1985, del régimen electoral general. Versión vigente desde 08/09/2001 hasta 31/03/2015.

**** Code électoral. Version consolidée du code au 19 juin 2012. Edition 26 août 2012.

**** Direzione Centrale dei Servizi Elettorali, le leggi elettorali. Elezioni politiche, 2011 (testo unico delle leggi recanti norme per la elezione della (amera dei Deputati).

***** TIMUR, F. B. Voting rights for Indonesian Armed Forces (TNI) personnel:yes, no or with reservation? Indonesia: Friedrich Ebert Stiftung, [s.d.]. Disponivel em:<http://www.fes.or.d//fes/download/201008_TN1\%20Voting\%20Rights.pdf>.

Nas próximas seções trataremos do perfil social e político-partidário desses candidatos.

\section{As candidaturas das Forças Repressivas de Estado}

Entre 2009 e 2013, ao menos 11.197 civis foram mortos pela polícia brasileira. No mesmo período, 1.770 policiais foram vitimados (Lima e Bueno, 2015). O $9^{\circ}$ Anuário Brasileiro de Segurança Pública apontou ainda um crescimento de $37,2 \%$ na letalidade policial em 2014 em relação a 2013. Foram 3.009 pessoas mortas, uma a cada três horas (op. cit., p. 6). De uma forma geral, os "atos de resistência 
seguidos de morte", como são juridicamente nominadas as mortes causadas por policiais, ou as "mortes sob confronto", como se referem as forças e seus comandos militares e políticos, são aceitos ou mesmo esperados pela sociedade brasileira. A bem-sucedida candidatura a deputado federal de um delegado da Polícia Civil do estado do Pará é exemplar da relação que a sociedade brasileira mantém com a violência institucionalizada do trabalho policial. Na ativa há 30 anos, o delegado Eder Mauro Cardoso Barra (PSD-PA) não se declarou como policial civil ao TSE, mas sim como "servidor público estadual". Pelos critérios deste trabalho, ele não integra a soma total dos casos analisados. Por outro lado, o nome de urna utilizado pelo candidato foi "Delegado Eder Mauro" e todo seu discurso eleitoral pautou-se na experiência profissional que lhe rendeu a alcunha de "xerife do Pará". Ele foi eleito deputado federal em 2014 com 7,08\% dos votos válidos, o mais votado no seu estado. Em sua primeira candidatura, ele rendeu ao PSD 265.983 votos, convertendo-se em um "puxador de votos". Seu discurso faz jus à sua alcunha - xerife do Pará -, pois resume a essência do pensamento nacional mais radical em relação à segurança pública: "bandido bom é bandido morto.". ${ }^{17}$

\section{A dinâmica das candidaturas}

O gráfico 1 dá uma ideia exata do aumento progressivo do número de candidatos das Forças de Segurança do Estado até 2006 e sua acomodação em 2014 ao padrão de 1998.

17 Brasil (2015). O jingle de campanha do candidato é uma paródia do tema musical do filme Tropa de Elite (2007), de José Padilha, sobre a ação do Batalhão de Operações Policiais Especiais (Bope) da Polícia Militar do Rio de Janeiro. A letra do jingle de campanha diz: "Eder Mauro chegou pra [sic] resolver / agora um deputado federal você vai ter [...]. Chefe de família, grande policial / homem de coragem, defendia o bem do mal. O Pará precisa, o povo sabe e quer / Delegado Eder Mauro, homem de fé". 
Gráfico 1 - Percentual de candidatos das Forças Repressivas a deputado federal no Brasil sobre o total de competidores por eleição, 1998-2014

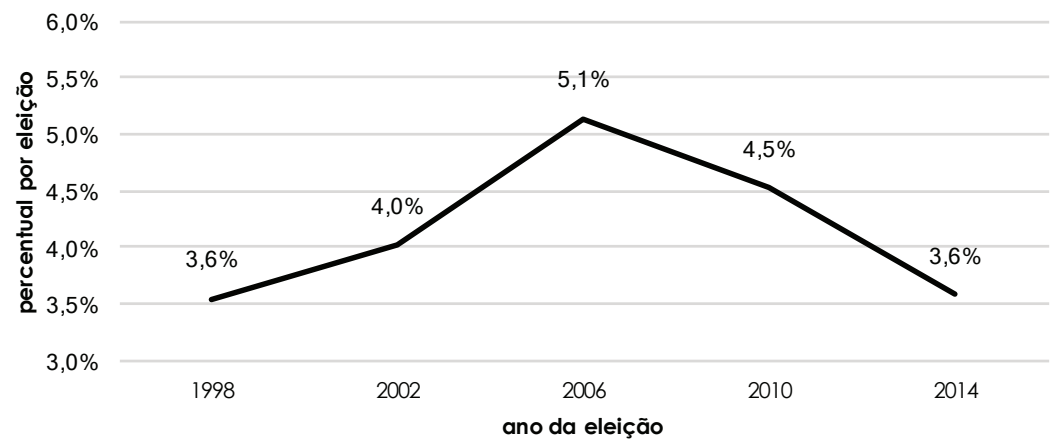

Fonte: Observatory of Social and Political Elites of Brazil (disponivel em: <http://observatory-elites.org/>), e Nusp/UFPR.

Entre 1998 e 2014, o número de candidatos a deputado federal nessa categoria profissional cresce quase 90\%, passando de 120 para 209. Todavia, em termos percentuais, o total de policiais-candidatos é o mesmo no início e no fim dessa série: 3,6\%. Há um pico em 2006 (254 candidatos, 5,1\% do total) que merece uma explicação mais detalhada.

Em 2006 ocorreram as primeiras grandes demonstrações de força do Primeiro Comando da Capital (PCC), uma organização cuja origem se deu nas prisões do estado de São Paulo nos anos 1990 e que hoje está presente na quase totalidade das instituições penais e na maior parte das zonas urbanas daquele estado. Houve uma série de rebeliões - precisamente em 74 unidades prisionais de São Paulo, simultaneamente - comandadas pelo PCC em maio de 2006 e que alcançaram diversos estados brasileiros (Espírito Santo, Paraná, Mato Grosso do Sul, Minas Gerais e Bahia). Fora dos presídios houve conflitos, depredações e muitas execuções. Segundo levantamento feito pelo Laboratório de Análises da Violência da Universidade Estadual do Rio de Janeiro (UERJ), foram 564 os mortos por arma de fogo entre 12 e 21 de maio de 2006, entre eles 505 civis e 59 agentes públicos. Durante as semanas seguintes, foram executados mais 500 civis. Em um mês 
foram mortas mais de mil pessoas na reação da polícia aos denominados "ataques do PCC" (Adorno e Salla, 2007). ${ }^{18}$ A semana da ofensiva do PCC teve cobertura diuturna na imprensa e repercutiu em todo o Brasil. Foi um período de grande agitação que mobilizou governos, Forças Policiais, mídia e população não apenas dos estados envolvidos, mas de todo o país, que pode acompanhar diariamente a divulgação dos acontecimentos. Análise da cobertura da mídia durante os "ataques do PCC" em 2006 constatou que a palavra mais utilizada pelos jornais impressos do estado de São Paulo foi de "guerra urbana" (Ribeiro, 2014). Um dos momentos cruciais da semana foi a interrupção da programação da maior rede de televisão do país (TV Globo) para a divulgação de um vídeo gravado por integrante do PCC em troca da liberação do jornalista Alexandre Calado, que havia sido sequestrado. Ribeiro defende que as informações divulgadas pela imprensa, ao privilegiar as fontes oficiais, não deram oportunidade de expressão aos líderes do PCC que, por meio de demonstração de força e uso da violência, procuravam também chamar a atenção para as condições do sistema carcerário e fazer reivindicações ao poder público. Segundo ela, "tratou-se de uma medida drástica para que seus enunciados fossem escutados" (Ribeiro, 2014, p. 12).

O evento e sua divulgação espetacular ressaltou a sensação de insegurança cotidiana e elevou o nível de atenção ao tema ao explicitar, entre outras coisas, uma coordenação de ações a partir do sistema carcerário e o clima de "guerra particular" existente entre agentes públicos de segurança e integrantes do PCC. Os acontecimentos possivelmente contribuíram para o aumento de $4 \%$ (2002) para 5,1\% (2006) do contingente de candidatos a deputado federal das Forças de Segurança. Nas eleições seguintes essa taxa baixa progressivamente, mas ainda assim se mantém significativa (3,6\% do total de candidatos em 2014).

Se desagregarmos os dados em duas classes de "polícias", civil e militar, constatamos o enorme predomínio de militares (policiais

18 Vera cronologia dos atos de violência no Brasil em 2006, disponível em:<http://pt.wikipedia.org/w/ index.php?title=Cronologia_dos_atos_de_viol\%C3\%AAncia_no_Brasil_em_2006\&redirect=no>. 
militares, militares da ativa/inativos e bombeiros militares). $\mathrm{O}$ gráfico 2 exibe a distribuição desigual entre os dois grupos.

Gráfico 2 - Percentual de candidatos das Forças Repressivas (Civis e Militares) a deputado federal no Brasil, 1998-2014

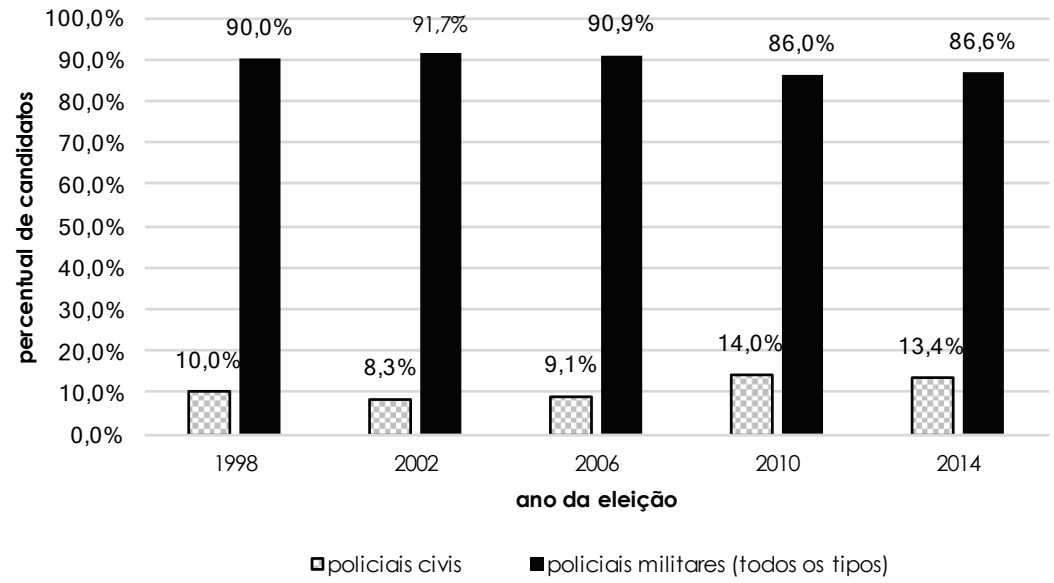

Fonte: Observatory of Social and Political Elites of Brazil (disponivel em: <http://observatory-elites.org/>), e Nusp/UFPR.

Houve, nessa série histórica, um máximo de 31 candidatos da Polícia Civil em 2010 (contra 190 dos militares), mas, em geral, essa categoria fica em torno dos $11 \%$ dos concorrentes a deputado nesse grupo. Esse valor, contudo, tem aumentado ao longo do período.

\section{Sociografia característica dos candidatos a deputado federal}

Assim como no campo da política profissional, as polícias são universos masculinos. Pesquisa sobre o perfil das instituições de segurança pública no Brasil (Figueiredo e Neme, 2013) mostrou que, em 2011, a composição feminina das Polícias Militares e dos Bombeiros era apenas de 7,2\% e 7,9\%, respectivamente. Na Polícia Civil, o efetivo nacional de mulheres era de $25 \%$ do total. Excluído o conjunto de candidatos aqui observados (polícia/militares), os 
dados mostram que há quase $82 \%$ de indivíduos do sexo masculino, contra $18 \%$ do sexo feminino entre os demais candidatos (tabela 2). É uma diferença menor do que encontramos nos candidatos da Polícia Civil (90\% contra 10\%), mas nas instituições militares a diferença entre homens e mulheres aumenta ainda mais ( $96 \%$ contra $4 \%)$.

Tabela 2 - Dados sociográficos dos candidatos das Forças Repressivas (Civis e Militares) a deputado federal, de 1998 a 2014, comparados aos demais candidatos

\begin{tabular}{|c|c|c|c|c|c|c|c|}
\hline & & \multicolumn{4}{|c|}{ Civil e Militar } & \multirow{3}{*}{$\begin{array}{c}\text { Demais } \\
\text { candidatos }\end{array}$} & \multirow{3}{*}{ Média } \\
\hline & & \multicolumn{2}{|c|}{ Civil } & \multicolumn{2}{|c|}{ Militar } & & \\
\hline & & $\%$ & Média & $\%$ & Média & & \\
\hline \multirow{2}{*}{ Sexo } & Feminino & $10,2 \%$ & & $3,9 \%$ & & $18,3 \%$ & \\
\hline & Masculino & $89,8 \%$ & & $96,1 \%$ & & $81,7 \%$ & \\
\hline \multirow{3}{*}{ Situação conjugal } & Casado(a) & $65,7 \%$ & & $73,6 \%$ & & $60,7 \%$ & \\
\hline & Outras situações & $34,3 \%$ & & $26,0 \%$ & & $38,6 \%$ & \\
\hline & Sem informação & $0,0 \%$ & & $0,3 \%$ & & $0,7 \%$ & \\
\hline \multirow{3}{*}{ Educação } & Ensino Superior * & $83,3 \%$ & & $57,5 \%$ & & $56,7 \%$ & \\
\hline & Sem Ensino Superior & $16,7 \%$ & & $42,2 \%$ & & 47,8 & \\
\hline & Sem informação & $0,0 \%$ & & $0,2 \%$ & & 0,5 & \\
\hline \multicolumn{2}{|c|}{ Idade na data da eleição } & & 47 & & 46 & & 45 \\
\hline
\end{tabular}

Fonte: Observatory of Social and Political Elites of Brazil (disponivel em: <http://observatory-elites.org/>), e Nusp/UFPR. Nota: * Completo ou não.

Os dados nos mostram também que a qualificação universitária entre os candidatos civis é bem maior que a dos militares ( $83 \%$ contra 57\%), o que é um retrato fiel das corporações, já que a maioria das carreiras na Polícia Civil exige curso superior para o ingresso e a ascensão. A distribuição de diplomados ou em vias de se diplomar entre os militares segue o perfil dos candidatos em geral. 
Sobre a média de idade na data da disputa, o número acompanha o perfil encontrado também nos candidatos de outras origens ocupacionais. Ou seja, quando comparados com os demais candidatos, não há grandes diferenças.

\section{Candidaturas por blocos ideológicos: a ascensão dos pequenos partidos}

O gráfico 3 registra que quase $70 \%$ dos candidatos vindos das polícias apresentaram-se para concorrer a uma cadeira na Câmara dos Deputados por partidos à direita no espectro político. Mostra, ainda, que o total destes candidatos em partidos de direita é bem superior ao valor registrado para os demais candidatos nos mesmos partidos no período analisado (53\%).

Gráfico 3 - Distribuição percentual dos candidatos das Forças Repressivas a deputado federal no Brasil por espectro ideológico, período 1998-2014

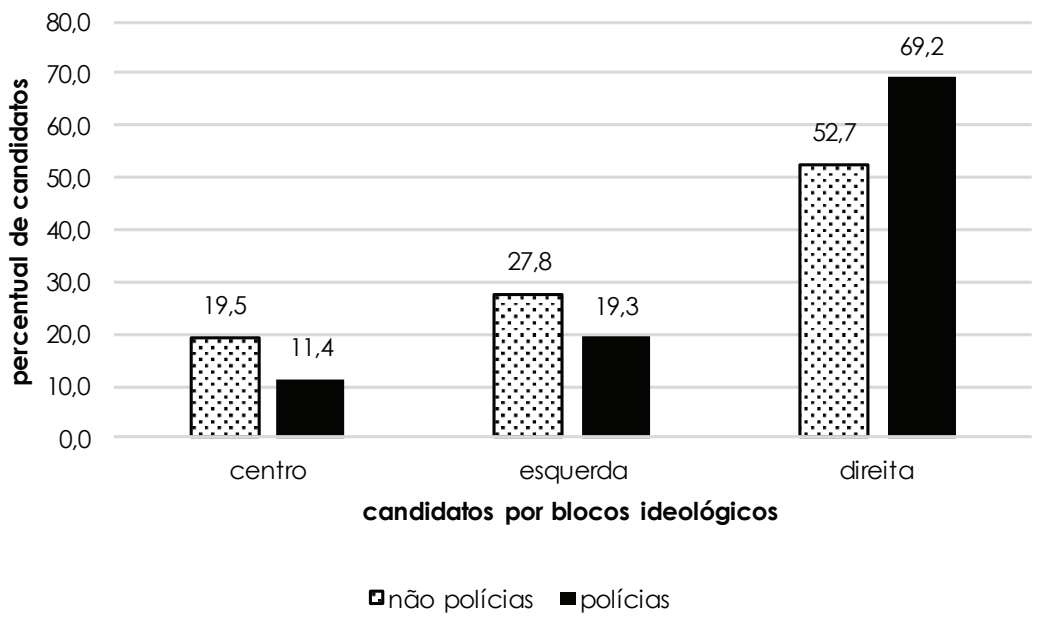

Fonte: Observatory of Social and Political Elites of Brazil (disponível em: <http://observatory-elites.org/>), e Nusp/UFPR. Obs.: Número de casos válidos $=972$. 
A informação do gráfico 3 é muito agregada e não mostra mais do que dedutivamente seria esperado sobre esse grupo de candidatos, ou seja, que ele se apresenta mais para concorrer politicamente por partidos de direita. Além do peso das variáveis institucionais características dos partidos de preferência deste grupo de candidatos, e que serão explicadas em seguida, há variáveis mais sociológicas implicadas aqui.

$\mathrm{Na}$ escala de valores presentes nas instituições de origem desses candidatos, ao menos na dos militares que formam a grande maioria do contingente analisado, a disciplina, a autoridade e a hierarquia são os valores que mais fortemente condicionam sua cultura profissional. Por dedução, há grande chance de existir afinidade entre os valores apreendidos na socialização institucional e aqueles condizentes com as agendas dos partidos de direita, menos tolerantes com as liberdades individuais, por exemplo. Além do mais, é comum que a ideia de "mais segurança" pública, presente nas plataformas de partidos de direita, dependa de estratégias como "maior reforço do aparato policial (contingente, recursos, equipamentos), maiores taxas de encarceramento, porte de armas para garantir a autodefesa dos indivíduos, diminuição da maioridade penal, penas mais severas" (Babireski, 2016, p. 10). Esse expediente tem força entre membros das Forças Repressivas que "herda[m] e reproduz[em] uma trajetória de intervenção estatal orientada por estratégias de autopreservação, repressão e controle autoritário da ordem" (Santos, Gontijo e Amaral, 2015, p. 111).

No item seguinte, veremos a distribuição desses candidatos pelas siglas partidárias de maneira mais detalhada. A categorização dos partidos aqui proposta permitirá apreender as transformações na dinâmica política dessa população de candidatos. Se a grande maioria alista-se para concorrer a deputado por partidos de direita, nem sempre é a mesma direita e, ao longo do tempo, há transformações relevantes nas preferências partidárias desse grupo ou nas oportunidades que são abertas aos candidatos para empreenderem politicamente. 


\section{Dissecando a filiação partidária dos candidatos-policiais}

Quando desagregamos os partidos por tamanhos (grandes e pequenos) e por ideologias (direita, centro e esquerda) ou sem ideologias muito claras ("fisiológicos"), encontramos três informações relevantes: $i$ ) a diminuição quase constante do número desses candidatos pelos grandes partidos de direita; $i$ ) a concentração de $1 / 3$ dos candidatos desse grupo em pequenos partidos de direita, exceto em 2002, quando os grandes de esquerda cumprem um papel relevante para viabilizar estes candidatos; e iii) o aumento significativo no número dos candidatos-policiais por pequenos partidos fisiológicos: de apenas $10 \%$ do total de concorrentes em 1998, passou-se a 22,5\% em 2014 (tabela 3). 
Tabela 3 - Distribuição dos candidatos das Forças Repressivas a deputado federal no Brasil por tipo de partido político, de 1998 a 2014 (em números absolutos e percentuais)

\begin{tabular}{|c|c|c|c|c|c|c|c|c|}
\hline & \multirow{2}{*}{$\begin{array}{l}\text { Tipos de partidos } \\
\text { políticos }\end{array}$} & & \multicolumn{5}{|c|}{ Ano de eleição } & \multirow{2}{*}{ Total } \\
\hline & & & 1998 & 2002 & 2006 & 2010 & 2014 & \\
\hline \multirow{14}{*}{ Candidatos-policiais } & \multirow{2}{*}{ Grande de centro } & $\mathrm{N}$ & 11 & 14 & 7 & 17 & 13 & 62 \\
\hline & & $\%$ & $9,2 \%$ & $8,3 \%$ & $2,8 \%$ & $7,7 \%$ & $6,2 \%$ & $6,4 \%$ \\
\hline & \multirow{2}{*}{ Grande de direita } & $\mathrm{N}$ & 28 & 32 & 28 & 34 & 31 & 153 \\
\hline & & $\%$ & $23,3 \%$ & $19,0 \%$ & $11,0 \%$ & $15,4 \%$ & $14,8 \%$ & $15,7 \%$ \\
\hline & \multirow{2}{*}{ Grande de esquerda } & $\mathrm{N}$ & 22 & 37 & 41 & 28 & 23 & 151 \\
\hline & & $\%$ & $18,3 \%$ & $22,0 \%$ & $16,1 \%$ & $12,7 \%$ & $11,0 \%$ & $15,5 \%$ \\
\hline & \multirow{2}{*}{ Pequeno de centro } & $\mathrm{N}$ & 6 & 24 & 31 & 13 & 9 & 83 \\
\hline & & $\%$ & $5,0 \%$ & $14,3 \%$ & $12,2 \%$ & $5,9 \%$ & $4,3 \%$ & $8,5 \%$ \\
\hline & \multirow{2}{*}{ Pequeno de direita } & $\mathrm{N}$ & 41 & 37 & 89 & 77 & 75 & 319 \\
\hline & & $\%$ & $34,2 \%$ & $22,0 \%$ & $35,0 \%$ & $34,8 \%$ & $35,9 \%$ & $32,8 \%$ \\
\hline & \multirow{2}{*}{$\begin{array}{l}\text { Pequeno de } \\
\text { esquerda }\end{array}$} & $\mathrm{N}$ & 0 & 0 & 12 & 14 & 11 & 37 \\
\hline & & $\%$ & $0,0 \%$ & $0,0 \%$ & $4,7 \%$ & $6,3 \%$ & $5,3 \%$ & $3,8 \%$ \\
\hline & \multirow{2}{*}{ Pequeno fisiológico } & $\mathrm{N}$ & 12 & 24 & 46 & 38 & 47 & 167 \\
\hline & & $\%$ & $10,0 \%$ & $14,3 \%$ & $18,1 \%$ & $17,2 \%$ & $22,5 \%$ & $17,2 \%$ \\
\hline & \multirow{2}{*}{ Total } & $\mathrm{N}$ & 120 & 168 & 254 & 221 & 209 & 972 \\
\hline & & $\%$ & $100,0 \%$ & $100,0 \%$ & $100,0 \%$ & $100,0 \%$ & $100,0 \%$ & $100,0 \%$ \\
\hline
\end{tabular}

Fonte: Observatory of Social and Political Elites of Brazil (disponível em: <http://observatory-elites.org/>), e Nusp/UFPR. Obs.: Coeficiente de contingência 0,271; $p$-value 0,000; número de casos válidos $=972$.

Em 1998, o predomínio dos pequenos partidos de direita é evidente (34,2\% dos concorrentes) e mais de um terço deles se apresentam aos eleitores pelo PSC (13,3\%). Em segundo lugar, temos os grandes de direita $(23,3 \%)$ e esses candidatos estão principalmente no PFL $(9,2 \%)$ e no PPB $(7,5 \%)$. Essa preferência por pequenos de direita sofre uma queda importante na eleição seguinte, chegando a 22\%, mesmo valor dos grandes de esquerda: apenas o PSB responderá por $11,9 \%$ dos policiais na disputa 
de uma vaga na Câmara dos Deputados em 2002. Em 2006, os grandes de direita respondem por menos da metade do valor de 1998 (apenas 11\%) e pelo PPB concorrem apenas 1,6\% desse grupo. Os pequenos de direita voltam a reunir o maior número de pretendentes ao cargo. Foi também no ano de 2006 em que houve mais candidaturas das polícias a deputado federal: 254 de um total de 4.689 concorrentes (ver a tabela 1 e o gráfico 1 mais acima). Apenas o PRP, um dos pequenos de direita, partido anteriormente dirigido por Ademar de Barros Filho, lançaria 38 policiais destes 254 (ou 15\%).

Se olharmos a distribuição dos percentuais dos demais candidatos (não policiais), há também um decréscimo da participação dos grandes partidos de direita no conjunto das candidaturas a deputados no Brasil, mas ela é bem menos espetacular (de 24,8\% em 1998 para $17,2 \%$ em 2006). Essa volta para os pequenos partidos de direita em 2006 (35\%) é também fruto da fragmentação partidária e da abertura dessas siglas a discursos personalistas, que são como os candidatos-policiais apresentam-se, donos de um projeto próprio e não ligados à história de um partido específico.

A participação dos candidatos nos grandes partidos de esquerda cai progressivamente de 2002 a 2014. Isso porque vemos o surgimento, a partir da eleição de 2006, de candidatos-policiais por pequenos partidos de esquerda, o que não havia ocorrido até então. Em 2010, o PSOL responderá por 6,3\% desses candidatos, quase empatado no terceiro lugar com PSB e PTB. Seria possível imaginar que a esquerda tenha pulverizado seus candidatos, com o PSOL roubando candidatos que tenderiam a sair pelo PT. Ocorre que, entre os grandes de esquerda, o PT é o que menos apresentou candidatos com origens nas Forças de Segurança do Estado: apenas 19 em todo o período 1998-2014. Já o PSB apresentou 68 e o PDT 64 candidatos nas últimas cinco disputas para a Câmara Federal. ${ }^{19}$

19 A diferença mais marcante que encontramos entre os candidatos desses partidos é de posição hierárquica institucional. Enquanto os oficiais são raros e os delegados inexistentes no PSOL, no PSB e no PDS eles são frequentes. 
Há, nesses dados, mais um grande aspecto a destacar. Quando olhamos para a tabela 3 não há, por parte desse grupo, qualquer opção consistente ao longo do tempo por partidos de um único perfil, apesar da dominância dos pequenos de direita. Os valores que indicam os contingentes principais de candidatos em partidos de direita e em partidos de esquerda oscilam fortemente entre uma eleição e outra. Em 1998, o PDT (esquerda) apresentou 10\% desses candidatos; em 2002, o PSB (esquerda) tinha 12\%; em 2010, o PSL (direita) apresentou 12\%; em 2014, o PEN (direita) tinha $8 \%$, por exemplo.

Essa ausência de fidelidade dos candidatos-policiais a um perfil partidário fixo pode bem resultar de duas coisas: pode ser um produto da indiferença desses atores aos grandes valores representados por ideologias políticas concorrentes (Estado versus mercado, igualdade versus liberdade etc.), ou, mais propriamente, da negação de ideologias e de programas políticos com apelos muito genéricos ("liberdade de mercado", "redução das desigualdades", "igualdade de oportunidades" etc.). Por outro lado, essa inconstância pode ser efeito da opção por um comportamento politicamente estratégico. Isso coincide com a concentração dessas candidaturas nos pequenos de direita e com o crescimento desse grupo nos partidos fisiológicos, os endereços mais ajustados para a atração desse tipo de concorrente. Nessas pequenas legendas, obter um lugar na lista é bem mais simples do que nas grandes, assim como entrar e sair delas, pois não há grandes barreiras institucionais e os vínculos partidários tendem a ser mais efêmeros, pois é o indivíduo que empresta densidade eleitoral ao partido, e não o contrário.

O gráfico 4, a seguir, mostra esses mesmos dados da tabela 3, mas em resíduos padronizados ajustados, o que nos dá uma ideia mais precisa da mudança de concentração das candidaturas dos agentes das Forças Repressivas ao longo do tempo e o caminho que vai dos grandes partidos de direita para os partidos sem perfil 
ideológico claro ao final da série. O limite de significância dos dados é acima de 1,96 positivo ou negativo. ${ }^{20}$

Gráfico 4 - Distribuição dos candidatos das polícias a deputado federal no Brasil, de 1998 a 2014, por tipo de partido político (resíduos padronizados ajustados)

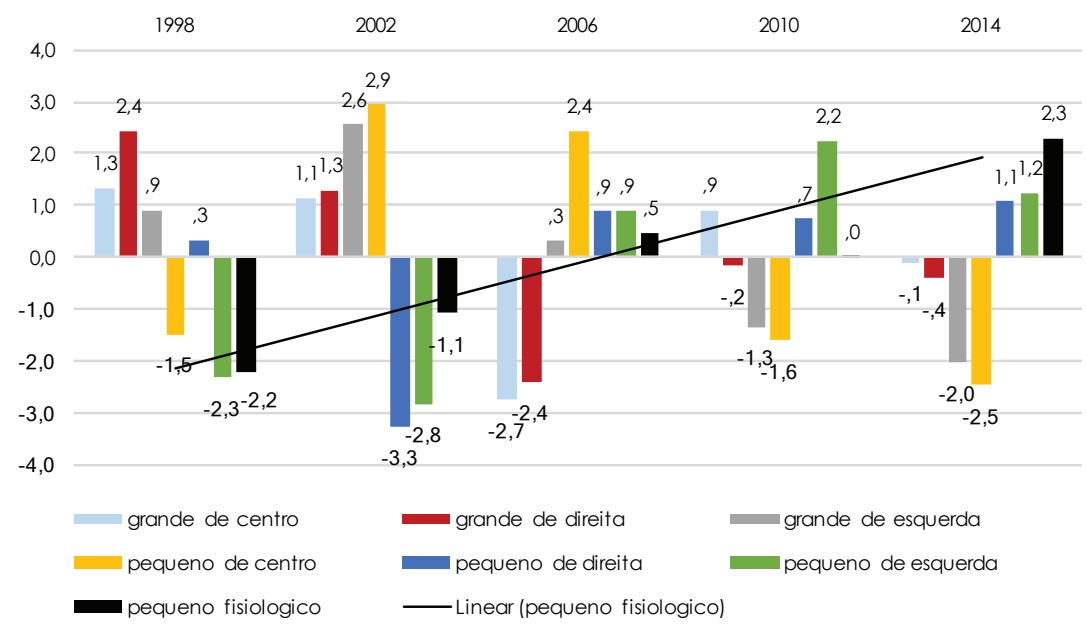

Fonte: Observatory of Social and Political Elites of Brazil (disponivel em: <http://observatory-elites.org/>), e Nusp/UFPR.

O caso dos partidos fisiológicos é especialmente interessante, já que eles passam de 10,0\% dos candidatos, no início da série, a 22,5\% ao final (tabela 3). Os valores em resíduos ajustados mostram uma pequena sub-representação em $1998(-2,2)$ e uma pequena super-representação em $2014(+2,3)$. Nesse sentido, se nos pequenos partidos de direita a possibilidade de ter um lugar na lista é muito maior do que nos grandes partidos, partidos fisiológicos oferecem

20 Se os resíduos padronizados ajustados situam-se no intervalo entre -1,96 a 1,96, isso significa que a contagem observada naquela célula da tabela é semelhante à contagem esperada ou semelhante à média. Portanto, "não há nada de novo a relatar", isto é, não há nada de especial acontecendo. Quando estes resíduos estão abaixo de -1,96, a célula "tem um comportamento significativamente inferior ao esperado. [...] Quando estes resíduos se situam [...] acima de 1,96 significa que essa célula tem um comportamento significativamente superior ao esperado, ou superior à média" (Pestana e Gageiro, 2008, p. 133). Assim, quanto maiores os resíduos, maior a associação (negativa ou positiva) entre as variáveis. 
ainda mais chance para candidatos que representam agendas de grupos bastante localizados, pois exercem menos controle sobre plataformas e discursos de nicho. São partidos que dão espaço para candidaturas corporativistas, focadas nas reputações pessoais de candidatos, e não em uma agenda programática que forneça algum amálgama entre a plataforma do partido e a de seus candidatos. Um pouco mais de $22 \%$ dos agentes de segurança e repressão do Estado disputaram as eleições de 2014 por pequenos partidos fisiológicos, com destaque para o PT do B $(6,7 \%)$ e o PHS $(6,2 \%)$.

Uma segunda constatação são as mudanças bruscas de uma eleição a outra entre os tipos de partidos nos quais essas candidaturas mais se concentram positivamente: em 1998, nos grandes de direita (resíduos de $+2,4$ ); em 2002, nos pequenos de centro $(+2,9)$ e nos grandes de esquerda $(+2,6)$; em 2006, nos pequenos de centro $(+2,4)$; em 2010 , nos pequenos de esquerda $(+2,2)$; e em 2014, nos pequenos partidos fisiológicos $(+2,3)$.

Com base nas observações, podemos sugerir que essa flutuação partidária estaria ligada a quatro ordens de fatores: i) legal; ii) político; iii) organizacional; iv) ideológico.

O primeiro fator diz respeito ao impedimento constitucional de militares filiarem-se a partidos políticos, exceto depois que são consagrados candidatos. Isso faz com que os laços de lealdade com as organizações partidárias sejam altamente efêmeros e a escolha dessa ou daquela sigla muito contingente e ligada a fatores regionais, pessoais etc.

O segundo fator diz respeito à estratégia política adotada pelos partidos pequenos de lançarem muitos candidatos, inflacionando suas listas. Essas legendas beneficiam-se de uma relação de comensalismo eleitoral, dando espaço para campanhas candidato-centradas, ao mesmo tempo em que o voto disperso conta para a conquista de uma ou outra cadeira. Foi o que ocorreu em 2014. Perto de $30 \%$ do total de candidatos concorreram por essas pequenas siglas (e quase 13\% deles, pelos fisiológicos). 
O terceiro fator tem a ver com o potencial eleitoral das demandas por reformas nas estruturas das polícias, o que pode ser mais bem percebido nas eleições de 2014. Vários dos candidatos destacados em função do seu papel de liderança nos movimentos grevistas dos últimos anos tiveram sucesso. ${ }^{21} \mathrm{O}$ potencial eleitoral das questões corporativas pode ser observado também na lista de candidatos pertencentes a esse grupo e que se apresentaram pelo PSOL. Entre os 29 indivíduos, encontramos seis militantes de associação de classe. O caso emblemático (o único que obteve uma cadeira) é o do deputado federal Cabo Daciolo (ex-PSOL-RJ). Ele recebeu 49.831 votos, a maioria vinda, possivelmente, de militares do estado do Rio de Janeiro, que somam 127 mil homens, 22 mil somente do Corpo de Bombeiros, sua instituição de origem. Seu engajamento político deu-se a partir da atuação como um dos líderes da grande manifestação da classe dos bombeiros militares do Rio de Janeiro em 2011, a SOS Bombeiros. Em 2012, ele foi expulso da corporação com mais 13 colegas acusado de vários crimes militares, entre eles o de envolvimento com política partidária. Foi eleito, segundo ele, por "milagre", já que alegou não ter recebido sua cota do fundo partidário para campanha nem de tempo na televisão. Esta alegação foi feita durante seu discurso após ser expulso do PSOL, em maio de 2015, por infidelidade

21 Três estados da região Nordeste elegeram deputados estaduais cujas campanhas originaram-se de grandes greves das Polícias Militares. O Capitão Wagner (PR), da Polícia Militar do Ceará, era vereador desde 2012, em Fortaleza, e elegeu-se deputado estadual com a maior votação da história de seu estado: 194.200 votos. O Ceará também elegeu o líder Cabo Sabino como deputado federal, com 120.485 votos. Na Bahia, o soldado da Polícia Militar e já vereador pela capital, Marco Prisco (PSDB), elegeu-se para a Assembleia Estadual com 107 mil votos. Sua campanha foi construída por uma rede corporativa de apoio, já que o candidato cumpria pena de restrição de liberdade por liderar a greve da Polícia Militar da Bahia em vésperas de feriado de Páscoa. Em Pernambuco, o soldado da Polícia Militar Joel Maurino do Carmo (PROS) recebeu 19.794 votos. Elegeu-se deputado estadual puxado por um pastor evangélico. Outros líderes grevistas fizeram campanha, mas não foram eleitos. Ver <http://www1.folha.uol.com.br/ poder/2014/10/1529213-alguns-com-recorde-de-votos-policiais-grevistas-vencem-eleicoes-no-nordeste.shtml>. 
partidária. ${ }^{22} \mathrm{O}$ caso de Daciolo é extremo, mas pode mostrar que o fato de ter havido uma ampliação do percentual de candidatos dessas forças por partidos de esquerda não se dá sem tensões. Entre as suas estratégias de campanha, ao lado das propostas para melhorias trabalhistas entre policiais e bombeiros militares, está a construção ou o reforço da imagem de mártires da luta pela categoria. ${ }^{23}$

O quarto fator tem a ver com a posição valorativa que assumem contra a política institucional, os políticos de carreira e os partidos tradicionais. A filiação a partidos pequenos e a partidos fisiológicos apenas para disputar eleições visa se diferenciar dos políticos estabelecidos e do estilo de política que praticam.

Esse é um elemento ideológico - a visão negativa da política e dos políticos - muito presente entre as Forças Repressivas do Estado. As plataformas morais, baseadas na negação da atuação dos grandes partidos nacionais, acusados de corruptos, são um tema importante e recorrente na campanha desses candidatos. Eles encontram nos partidos nanicos um lugar mais oportuno para se manifestarem. Candidatos-policiais têm preferência por autodeclararem-se arautos da ética, da retidão e do trabalho disciplinado. Essa autoimagem está ainda mais presente quando são militares. É o que encontramos nas declarações do Cabo Sabino (PR/CE): "as pessoas querem políticos sérios e encontram no profissional de segurança essa essência, essa honradez, essa seriedade". ${ }^{24}$ Apesar de ter se declarado "vereador" nos registros do TSE, e por isso não

22 Daciolo, que é evangélico, apresentou uma Proposta de Emenda Constitucional que sugeria a inserção da frase "todo poder emana de Deus" no lugar de "todo poder emana do povo" e, o mais grave, segundo o parecer da Comissão de Ética do partido, defendeu a libertação dos 12 suspeitos de torturar e matar o pedreiro Amarildo em 2013 no Rio de Janeiro. O PSOL havia se engajado na campanha "Cadê Amarildo?" e milita na luta contra a criminalização dos moradores das periferias.

23 Outro perfil de "mártir" é como o do primeiro sargento do Exército Rogério da Silva Gomes, que cumpriu 26 dias de prisão em 2008 por ter denunciado irregularidades em licitações de material hospitalar no quartel onde esteve lotado (mais informações em: <http://www.istoe.com.br/colunas-e-blogs/coluna/1424_RICARDO+BOECHAT>). Ele foi candidato quatro vezes consecutivas pelo PSOL: a deputado federal em 2006, 2010 e 2014, e a vereador em 2012.

24 Disponível em: <http://eleicoes.uol.com.br/2014/noticias/2014/08/25/com-campanhas-milionarias-lideres-de-greves-da-pm-no-ne-tentam-eleicao.htm>. 
pertencer ao conjunto de indivíduos presentes no banco de dados desta pesquisa, o candidato usa sua identificação militar, "cabo", como nome de urna, tendo se inserido na política alavancado por sua liderança em greve da Polícia Militar cearense em 2012. No mesmo ano foi eleito vereador de Fortaleza e, em 2014, deputado federal com 120.485 votos. É a estratégia moralizadora da política que funda o $\mathrm{PMB}$, em processo de aprovação pelo TSE desde 2011, quando foi criado por José Augusto Rosa, Capitão da Polícia Militar do estado de São Paulo. O programa do PMB oferece aos eleitores a chance de eleger um partido cuja missão é "propiciar ao povo brasileiro uma opção de resgate da ética, da moral e, em especial, da honestidade na política nacional, valores tão cultuados pelos militares". O PMB promete ser uma "inovadora alternativa a todos aqueles que não mais acreditam nos partidos e nos políticos do Brasil, uma opção para moralizar o nosso amado país e promover uma profunda modificação da política e da realidade brasileira". ${ }^{25}$ Um dos números de legenda reivindicado pelo PMB é o 99, "para mostrar que estamos à extrema direita de tudo o que existe na política hoje", 26 justifica seu criador. Ainda sem a aprovação do PMB pelo TSE, Rosa, cujo nome político é Capitão Augusto, foi eleito deputado federal pelo PR de São Paulo em 2014 com 46.905 votos. O PR foi aliado de Dilma Rousseff para a reeleição à Presidência naquele pleito. Em sua defesa e do seu novo partido, Capitão Augusto argumentou que "nós [do PMB] não fazemos alianças, apoiamos pessoas" ${ }^{27}$

\section{Conclusões}

Este artigo procurou preencher uma lacuna nos estudos sobre a política brasileira ao investigar quem são, de onde vêm e para quais partidos vão os candidatos a deputado federal das Forças de Segurança do Estado brasileiro.

25 Programa do PMB, disponível em: <http://www.partidomilitar.com.br/?page_id=106>.

26 Disponível em: <http://epoca.globo.com/colunas-e-blogs/felipe-patury/noticia/2014/03/ com-320-mil-assinaturas-bpartido-militar-brasileirob-quer-o-numero-99.html>.

27 Disponível em: <http://www.cartacapital.com.br/blogs/carta-nas-eleicoes/critico-do-governo-capitao-augusto-lancara-sua-candidatura-a-deputado-pelo-pr-4053.html>. 
A visão usual sobre esses candidatos das "polícias" é a de que são exclusivamente de direita, defendem plataformas estritamente ideológicas, uma agenda conservadora em termos de costumes e estão unificados pelo discurso da repressão violenta à criminalidade. Isso tudo é verdadeiro, mas é parcialmente verdadeiro.

O total desses candidatos pertencentes a partidos de direita é superior ao dos demais candidatos no período analisado. Entretanto, ao desagregarmos os partidos por tamanhos, por ideologias ou sem ideologia (os “fisiológicos”), foi possível apreender características e transformações importantes ao longo do tempo na dinâmica política dessa população. Os dados indicam uma forte oscilação entre os grandes partidos de direita, os pequenos partidos de direita e os partidos fisiológicos entre uma eleição e outra. Entre 1998 e 2014, a porcentagem de candidatos das Forças Policiais nos partidos fisiológicos mais que dobrou, passando de $10 \%$ para $22,5 \%$.

Essa oscilação permitiu perceber ao menos duas características do grupo até agora: a primeira é que há forte inconstância partidária entre esses candidatos (isto é, ausência de preferência sistemática por esse ou aquele partido). Sugerimos que esta inconstância está ligada a certos fatores explicativos. O primeiro é o fator legal, ou seja, está ligada ao impedimento constitucional de militares filiarem-se a partidos políticos, exceto depois que são consagrados candidatos. O segundo fator diz respeito à estratégia política dos pequenos partidos em lançar muitos candidatos, inflacionando suas nominatas. $\mathrm{O}$ terceiro fator, que pode explicar a presença de candidatos com esse perfil também em partidos de esquerda ou mesmo de centro, tem a ver com demandas por reformas nas estruturas das polícias.

A segunda característica desse grupo é a indiferença, seja pela defesa de valores muito abstratos, representados por grandes ideologias (como "igualdade", "liberdade de mercado" etc.), seja pela assunção de uma plataforma político-partidária clara. Em vez disso, suas falas revelam a percepção, cada vez maior, do potencial político das demandas corporativas das Forças de Segurança 
Pública. Em 2014, candidatos com participação destacada na direção de movimentos grevistas tiveram um bom desempenho eleitoral. Foi justamente nos pequenos partidos fisiológicos em que eles encontraram o terreno para prosperar. Estes partidos têm, ao mesmo tempo, menos barreiras para integrar a lista de candidaturas, menos controle sobre o conteúdo das campanhas e dão mais oportunidades para lideranças personalistas que mantêm relações clientelares com grupos determinados.

\section{Referências}

ADORNO, S.; SALLA, F. Criminalidade organizada nas prisões e os ataques do PCC. Estudos Avançados, v. 21, n. 61, p. 7-29, set. 2007.

ALMEIDA, C.; LÜCHMANN, L. L.; RIBEIRO, E. Associativismo e representação política feminina no Brasil. Revista Brasileira de Ciência Política, n. 8, p. 237-263, ago. 2012.

ARAÚJO, C. M. O.; BORGES, D. Trajetórias políticas e chances eleitorais: analisando o "gênero" das candidaturas em 2010. Revista de Sociologia e Política, v. 21, n. 46, p. 69-91, jun. 2013.

ARAÚJO, P. M. Recrutamento parlamentar para o Senado e o perfil dos senadores brasileiros, 1989-2006. Política Hoje, v. 20, n. 2, p. 550-580, 2011.

BABIRESKI, F. R. Pequenos partidos de direita no Brasil: uma análise dos seus posicionamentos políticos. Newsletter - Observatório de Elites Políticas e Sociais do Brasil, v. 3, n. 6, p. 1-16, maio 2016.

BAIRD, M. F.; POLLACHI, N. O papel do Legislativo na segurança pública: análise da atuação da Comissão de Segurança Pública da Câmara dos Deputados em 2013. São Paulo: Instituto SoudaPaz, ago. 2014.

BOLOGNESI, B. Dentro do Estado, longe da sociedade: a distribuição do Fundo Partidário em 2016. Newsletter - Observatório de Elites Políticas e Sociais do Brasil, v. 3, n. 11, p. 1-15, jul. 2016.

BOLOGNESI, B.; PERISSINOTTO, R. M.; CODATO, A. Reclutamiento político en Brasil: mujeres, negros y partidos en las elecciones federales de 2014. Revista Mexicana de Ciencias Políticas y Sociales, v. 61, n. 226, p. 183-212, jan. 2016. 
BOURDIEU, P. La représentation politique: éléments pour une théorie du champ politique. Actes de la Recherche en Sciences Sociales, n. 36-37, p. 3-24, 1981.

BRASIL. Câmara dos Deputados. Discursos e Notas Taquigráficas. Sessão: 035.1.55.O. Orador: Delegado Éder Mauro. Data: 18/03/2015. Sumário: Debate sobre a segurança pública no Brasil. Brasília: Câmara dos Deputados, 2015. Disponível em: <http:// bit.ly/1PuHWdq>. Acesso em: 26 abr. 2015.

CAMPOS, L. A. O que afasta pretos e pardos da representação política? Uma análise a partir das eleições legislativas de 2014. In: ENCONTRO ANUAL DA ANPOCS, 39., 2015, Caxambu. Anais... Caxambu: Anpocs, out. 2015.

CAMPOS, L. A.; MACHADO, C. A cor dos eleitos: determinantes da sub-representação dos não brancos no Brasil. Revista Brasileira de Ciência Política, n. 16, p. 121-151, jan. 2015.

CANO, I. Políticas de segurança pública no Brasil: tentativas de modernização e democratização versus a guerra contra o crime. Sur - Revista Internacional de Direitos Humanos, v. 3, n. 5, p. 136155, dez. 2006.

CERVI, E. U. et al. Dinheiro, profissão e partido político: a vitória na eleição para deputado federal no Brasil em 2010. Sociedade e Estado, v. 30, n. 1, p. 189-205, jan. 2015.

CODATO, A.; CERVI, E. U.; PERISSINOTTO, R. M. Quem se elege prefeito no Brasil? Condicionantes do sucesso eleitoral em 2012. Cadernos Adenauer, v. 14, n. 2, p. 61-84, 2013.

CODATO, A.; FERREIRA, A. P. L.; COSTA, L. D. Do serviço público à Câmara dos Deputados: os parlamentares originários do funcionalismo público no Brasil. Revista do Serviço Público, v. 66, n. 4, p. 605-626, out. 2015.

COPPEDGE, M. A classification of Latin American political parties. Indiana: The Helen Kellogg Institute for International Studies, 1997.

The dynamic diversity of Latin American party systems. Party Politics, v. 4, n. 4, p. 547-568, out. 1998. 
DANTAS, H.; PRAÇA, S. Pequenos partidos no Brasil: uma análise do posicionamento ideológico com base nas coligações municipais de 2000 a 2008. In: KRAUSE, S.; DANTAS, H.; MIGUEL, L. (Eds.). Coligações partidárias na nova democracia brasileira: perfis e tendências. Rio de Janeiro; São Paulo: KonradAdenauer-Stiftung; Ed. Enesp, 2010. p. 99-133.

DIAP - DEPARTAMENTO INTERSINDICAL DE ASSESSORIA PARLAMENTAR (Org.). Radiografia do novo Congresso: legislatura 2015-2019. Brasília: Diap, 2014.

EDITORES DE OPINIÃO PÚBLICA. Encarte de dados: opinião sobre questões de segurança pública e comportamento social. Opinião Pública, v. 20, n. 3, p. 523-543, dez. 2014.

EV, L. S.; MELO, P. V. T. P. De onde vem e como sobrevivem os nanicos? Análise da votação dos pequenos partidos brasileiros. In: ENCONTRO ANUAL DA ANPOCS, 38., 2014, Caxambu. Anais...Caxambu: Anpocs, 2014.

FIGUEIREDO, I. S.; NEME, C. (Orgs.). Pesquisa perfil das instituições de segurança pública. Brasília: Ministério da Justiça, 2013.

GUARNIERI, F. A força dos partidos “fracos”. Dados, v. 54, n. 1, p. 235-258, 2011.

IBOPE - INSTITUTO BRASILEIRO DE OPINIÃO PÚBLICA E ESTATÍSTICA. 83\% da população é a favor da redução da maioridade penal. Ibope, 17 set. 2014. Disponível em: <http:// www.ibope.com.br/pt-br/noticias/paginas/83-da-populacao-ea-favor-da-reducao-da-maioridade-penal.aspx>. Acesso em: 15 maio 2015.

LIMA, R. S.; BUENO, S. (Orgs.). Anuário Brasileiro de Segurança Pública 2014. 8. ed. São Paulo: Fórum Brasileiro de Segurança Pública, 2015.

LIMA, R. S.; COSTA, A. T. Segurança pública. In: RATTON, J. L.; LIMA, R. S.; AZEVEDO, R. G. (Orgs.). Crime, polícia e justiça no Brasil. São Paulo: Contexto, 2014.

LLANOS, M.; SÁNCHEZ, F. Council of Elders? The Senate and its members in the Southern Cone. Latin American Research Review, v. 41, n. 1, p. 133-152, 2006. 
MADEIRA, R. M.; TAROUCO, G. S. Esquerda e direita no Brasil: uma análise conceitual. Revista Pós-Ciências Sociais, v. 8, n. 15, p. 171-186, 2011.

MADEIRO, C. Com campanhas milionárias, líderes de greves da PM no NE tentam eleição. UOL, 25 ago. 2014. Disponível em: <http://eleicoes.uol.com.br/2014/noticias/2014/08/25/ com-campanhas-milionarias-lideres-de-greves-da-pm-no-netentam-eleicao.htm>. Acesso em: 12 mar. 2015.

MARENCO DOS SANTOS, A. Nas fronteiras do campo político: raposas e outsiders no Congresso Nacional. Revista Brasileira de Ciências Sociais, v. 12, n. 33, p. 87-101, fev. 1997.

. Sedimentação de lealdades partidárias no Brasil: tendências e descompassos. Revista Brasileira de Ciências Sociais, v. 16, n. 45, p. 69-83, fev. 2001.

MENEGUELLO, R. et al. Mulheres e negros na politica: estudo exploratório sobre o desempenho eleitoral em quatro estados brasileiros. Campinas: Centro de Estudos de Opinião Pública; Universidade Estadual de Campinas, 2012.

MIGUEL, L. F.; MARQUES, D.; MACHADO, C. Capital familiar e carreira política no Brasil: gênero, partido e região nas trajetórias para a Câmara dos Deputados. Dados, v. 58, n. 3, p. 721-747, set. 2015.

NASCIMENTO, W. et al. Does size matter? Electoral performance of small parties in Brazil. Brazilian Political Science Review, v. 10, n. 2, p. 1-26, 2016.

NORRIS, P.; LOVENDUSKI, J. Political recruitment: gender, race, and class in the British parliament. Cambridge: Cambridge University Press, 1995.

PEREIRA, C.; RENNÓ, L. Should I stay or should I go? Explaining political ambition by electoral success. Journal of Politics in Latin America, v. 5, n. 3, p. 73-95, 2013.

PERISSINOTTO, R. M.; BOLOGNESI, B. Electoral success and political institutionalization in the Federal Deputy Elections in Brazil (1998, 2002 and 2006). Brazilian Political Science Review, v. 4, n. 1, p. 10-32, 2010. 
PERISSINOTTO, R. M.; VEIGA, L. F. Profissionalização política, processo seletivo e recursos partidários: uma análise da percepção dos candidatos do PT, PMDB, PSDB e DEM nas eleições para Deputado Federal de 2010. Opinião Pública, v. 20, n. 1, p. 49-66, abr. 2014.

PESTANA, M. H.; GAGEIRO, J. N. Análise de dados para ciências sociais: a complementaridade do SPSS. 5. ed. Lisboa: Sílabo, 2008. PIRES, S. F. S.; AMORIM, M. C. M. Elegibilidade e filiação partidária de militares. Brasília: Câmara dos Deputados, mar. 2006.

POWER, T. J.; MOCHEL, M. G. Shaping the Brazilian political class: causes and consequences of recruitment to the Chamber of Deputies. Canadian Journal of Latin American \& Caribbean Studies, v. 34, n. 67, p. 5-40, 2009.

POWER, T. J.; ZUCCO JR., C. Estimating ideology of Brazilian Legislative Parties, 1990-2005. Latin American Research Review, v. 44, n. 1, p. 218-246, 2009.

RAMOS, S.; PAIVA, A. (Org.). A blogosfera policial no Brasil: do tiro ao Twitter. Brasília: Centro de Estudos de Segurança e Cidadania; Universidade Candido Mendes; Unesco, out. 2009.

RIBEIRO, C. S. P. Violência na imprensa: a disputa pela verdade nos casos do PCC - 2006 e 2012. In: ENCONTRO DA ANDHEP - POLÍTICAS PÚBLICAS PARA A SEGURANÇA PÚBLICA E DIREITOS HUMANOS, 8., 2014, São Paulo. Anais... São Paulo: ANDHEP, 2014.

RODRIGUES, L. M. Eleições, fragmentação partidária e governabilidade. Novos Estudos Cebrap, n. 41, p. 78-90, 1995.

- Partidos, ideologia e composição social: um estudo das bancadas partidárias na Câmara dos Deputados. São Paulo: Edusp, 2002a.

- Partidos, ideologia e composição social. Revista Brasileira de Ciências Sociais, v. 17, n. 48, p. 31-47, fev. 2002b. . Mudanças na classe política brasileira. São Paulo: PubliFolha, 2006.

SALGADO, E. D. Os direitos políticos e os militares na Constituição de 1988. Paraná Eleitoral, v. 2, n. 3, p. 345-360, dez. 2013. 
SAMUELS, D. J. Determinantes do voto partidário em sistemas eleitorais centrados no candidato: evidências sobre o Brasil. Dados, v. 40, n. 3, 1997.

. Incentives to cultivate a party vote in candidate-centric electoral systems: evidence from Brazil. Comparative Political Studies, v. 32, n. 4, p. 487-518, jun. 1999.

SANTOS, I. G.; GONTIJO, J. G. L.; AMARAL, E. F. L. A política de segurança pública no Brasil: uma análise dos gastos estaduais (1999-2010). Opinião Pública, v. 21, n. 1, p. 105-131, abr. 2015.

SOARES, J. L. Apresentação. In: SENTO-SÉ, J. T. (Org.). Prevenção da violência: o papel das cidades. Rio de Janeiro: Civilização Brasileira, 2005.

SPECK, B. W.; MANCUSO, W. P. A study on the impact of campaign finance, political capital and gender on electoral performance. Brazilian Political Science Review, v. 8, n. 1, p. 34-57, 2014.

TAROUCO, G. S.; MADEIRA, R. M. Esquerda e direita no sistema partidário brasileiro: análise de conteúdo de documentos programáticos. Debates, v. 7, n. 2, p. 93-114, 2013a.

- Partidos, programas e o debate sobre esquerda e direita no Brasil. Revista de Sociologia e Política, v. 21, n. 45, p. 149-165, mar. 2013b.

VASCONCELOS, F. T. R. Esboço de uma sociologia política das ciências sociais contemporâneas (1968-2010): a formação do campo da segurança pública e o debate criminológico no Brasil. São Paulo: Universidade de São Paulo, set. 2014.

WEBER, M. The profession and vocation of politics. In: LASSMAN, P.; SPEIRS, R. (Eds.). Weber: political writings. Cambridge: Cambridge University Press, 1994. p. 309-369.

ZUCCO JR., C. Esquerda, direita e governo: a ideologia dos partidos políticos brasileiros. In: POWER, T. J.; ZUCCO JR., C. (Orgs.). O Congresso por ele mesmo: autopercepções da classe política brasileira. Belo Horizonte: Editora UFMG, 2011. p. 37-60. 


\section{Apêndice A}

Tabela A1 - Cálculo do tamanho dos partidos políticos no Brasil entre 1998 e 2014, conforme a média de cadeiras controladas ordenadas pelo $z$-score

\begin{tabular}{|c|c|c|c|}
\hline Partido & Média de cadeiras & Z-score & Tamanho \\
\hline PMDB & 78,40 & 2,76958 & Grande \\
\hline PT & 77,80 & 2,74331 & Grande \\
\hline PSDB & 68,60 & 2,34050 & Grande \\
\hline DEM/PFL & 63,80 & 2,13033 & Grande \\
\hline PP/PPB & 45,80 & 1,34221 & Grande \\
\hline PSD (K) & 37,00 & 95690 & Grande \\
\hline $\mathrm{PR} / \mathrm{PL}$ & 27,20 & ,52782 & Grande \\
\hline PSB & 27,20 & ,52782 & Grande \\
\hline PTB & 25,20 & ,44025 & Grande \\
\hline PDT & 23,20 & ,35268 & Grande \\
\hline SD & 15,00 &,- 00636 & Pequeno \\
\hline PPS & 12,40 &,- 12020 & Pequeno \\
\hline$P C$ do B & 11,40 & -16398 & Pequeno \\
\hline PROS & 11,00 &,- 18149 & Pequeno \\
\hline PRB & 10,00 &,- 22528 & Pequeno \\
\hline PSC & 8,20 &,- 30409 & Pequeno \\
\hline PV & 8,00 &,- 31285 & Pequeno \\
\hline PSD* $^{*}$ & 3,50 &,- 50988 & Pequeno \\
\hline PSOL & 3,67 &,- 50258 & Pequeno \\
\hline PRONA & 3,00 &,- 53177 & Pequeno \\
\hline PMN & 2,60 &,- 54929 & Pequeno \\
\hline PHS & 2,25 &,- 56461 & Pequeno \\
\hline PEN & 2,00 &,- 57556 & Pequeno \\
\hline PST & 2,00 &,- 57556 & Pequeno \\
\hline PRN/PTC & 1,20 &,- 61058 & Pequeno \\
\hline PRP & 1,00 &,- 61934 & Pequeno \\
\hline PSL & 0,80 &,- 62810 & Pequeno \\
\hline PT do B & 1,00 &,- 61934 & Pequeno \\
\hline PRTB & 0,60 &,- 63685 & Pequeno \\
\hline PSDC & 0,60 &,- 63685 & Pequeno \\
\hline PAN & 0,30 &,- 64999 & Pequeno \\
\hline$P C B$ & 0,00 &,- 66312 & Pequeno \\
\hline $\mathrm{PCO}$ & 0,00 &,- 66312 & Pequeno \\
\hline PGT & 0,00 &,- 66312 & Pequeno \\
\hline PPL & 0,00 &,- 66312 & Pequeno \\
\hline PSN & 0,00 &,- 66312 & Pequeno \\
\hline PSTU & 0,00 &,- 66312 & Pequeno \\
\hline PTN & 0,80 &,- 62810 & Pequeno \\
\hline
\end{tabular}

Elaboração própria. 


\section{Apêndice B}

\section{Quadro B1 - Lista de siglas dos partidos políticos brasileiros citados}

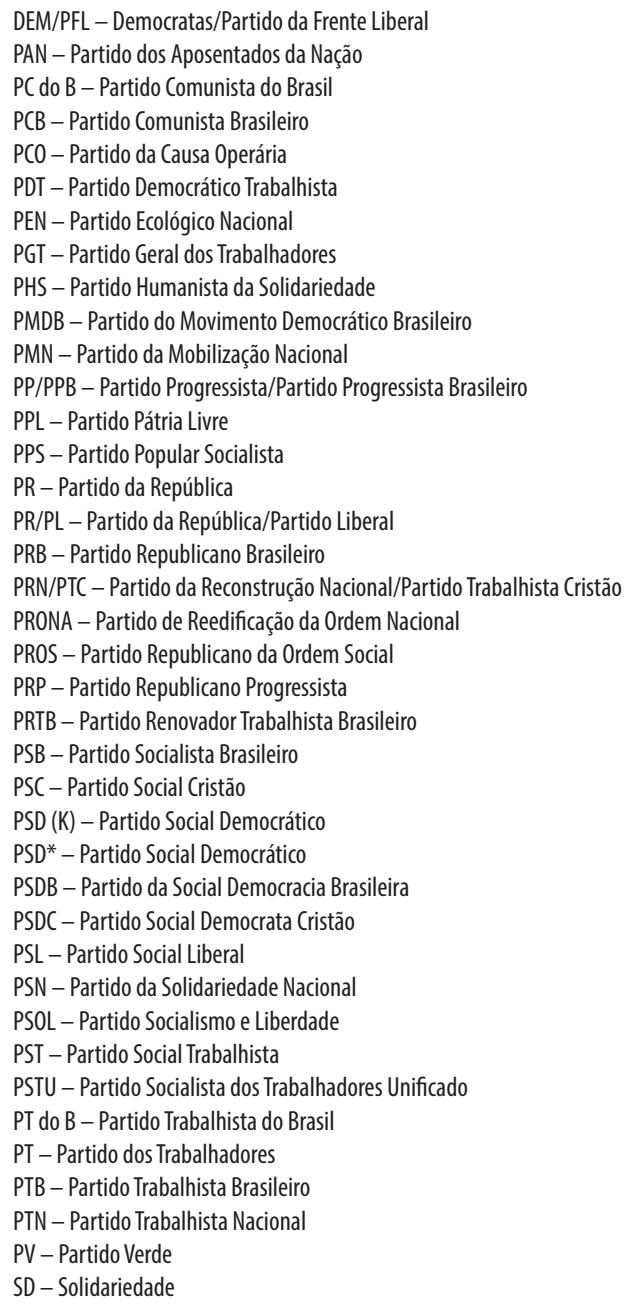

Elaboração própria. 


\section{Resumo}

Este artigo investiga o perfil social e a preferência partidária dos integrantes das Forças Repressivas do Estado que se lançaram na política institucional nas duas últimas décadas no Brasil. Por meio de estatística descritiva, ressaltamos as especificidades de integrantes das Forças Policiais e Militares que se candidataram a deputado federal. Achados desta pesquisa mostraram mudanças bruscas, de uma eleição a outra, entre os tipos de partidos nos quais essas candidaturas mais se concentraram. Se a passagem da polícia à política era feita, nos anos 1990, via grandes partidos de direita, nos anos 2010 ela se dá por meio de pequenos partidos sem identidade ideológica muito clara ("partidos fisiológicos"). Além do impedimento constitucional de militares filiarem-se a partidos políticos, a ausência de preferência sistemática por um tipo de agremiação partidária pode ser o efeito de um comportamento estratégico, já que obter um lugar na lista desses pequenos partidos não é apenas mais simples, mas há mais abertura a discursos personalistas, tais como os sustentados por esses candidatospoliciais. Esse comportamento também está relacionado à sua visão negativa da política tradicional e dos políticos estabelecidos nos grandes partidos e à crítica a programas com apelos ideológicos muito genéricos. Esses candidatos preferem representar agendas determinadas, como as demandas de suas próprias corporações.

Palavras-chave: forças repressivas do Estado; preferência partidária; perfil social; eleições; candidatos.

\section{Abstract}

The present article explores the social profile and political party preference by members of the State Repressive Forces with a career in institutional politics during the last two decades in Brazil. By means of descriptive statistics, we underline the particularities of Police and Military candidates for a federal deputy office. Findings from this research indicated abrupt changes, from one election to another, among the parties in which these candidates were most highly concentrated. If the transition from police to politics during the 1990s occurred through major right-wing parties, in the 2010 decade it takes place through small parties without clear ideological identities ("physiological parties"). In addition to the constitutional impediment of military personnel 
affiliation to political parties, the lack of a systematic preference for a party college type may be the effect of a strategic behavior, since not only is it easier to obtain a nomination within these small parties, but there also exists a greater lenience toward personalist discourses, such as those espoused by these policeperson-candidates. This behavior is also related to a negative view of traditional politics and established politicians within major parties as well as a condemnation of political programs with overly generic ideological appeals. Such candidates favor certain specific agendas, such as the demands from their own professional corporations.

Keywords: repressive forces of the State; party preference; social profile; elections; candidates.

Recebido em 14 de dezembro de 2015.

Aprovado em 27 de julho de 2016. 